\title{
44. DATA REPORT: GEOCHEMICAL LOGGING RESULTS FROM THREE LITHOSPHERIC PLATES; COCOS, NAZCA, AND PACIFIC: LEG 138, SITES 844 THROUGH 852 ${ }^{1}$
}

\author{
Lana B. Billeaud, ${ }^{2}$ Elizabeth Lewis Pratson, ${ }^{2}$ Cristina Broglia, ${ }^{2}$ Mitchell Lyle,${ }^{2}$ and Kathleen Dadey ${ }^{3}$
}

\begin{abstract}
Geochemical well logs were obtained through sediment at Sites 844 through 852 of Leg 138. Corrections have been applied to the logs to account for variations in borehole size, drilling-fluid composition, and drill-pipe attenuation. Concentrations of $\mathrm{Th}$, $\mathrm{U}$, and $\mathrm{Gd}$ and oxide-weight percentages were calculated from the logs and were compared with available X-ray fluorescence (XRF) core measurements. The geochemical processing was performed only for the openhole sections of Holes 844B, 845B, $846 \mathrm{~B}, 847 \mathrm{~B}, 849 \mathrm{~B}, 850 \mathrm{~B}$, and $851 \mathrm{~B}$. Both through-pipe and openhole sections were processed for Holes $848 \mathrm{~B}$ and $852 \mathrm{D}$. The $\mathrm{CaCO}_{3}$ core-log agreement is good throughout the sediment sections of Holes $844 \mathrm{~B}, 845 \mathrm{~B}, 846 \mathrm{~B}, 847 \mathrm{~B}, 849 \mathrm{~B}, 850 \mathrm{~B}, 851 \mathrm{~B}$, and for the openhole section of Hole 852D. The comparison of XRF core data to logging data is good for Holes 850B, 851B, and for the openhole section of 852D; and not as good, but with limited core sampling, for Holes 844B, 845B, and 849B. Holes 846B and 847B had no XRF core data for comparison in the logged intervals. Both the $\mathrm{CaCO}_{3}$ and the XRF core data compare poorly with the logged data from Hole $848 \mathrm{~B}$, which was logged almost entirely through pipe. The sections logged through pipe of Hole 852D compare poorly with $\mathrm{CaCO}_{3}$ core data; however, the comparison to XRF core data is relatively good except for $\mathrm{SiO}_{2}$.
\end{abstract}

\section{INTRODUCTION}

The primary objective of Leg 138 of the Ocean Drilling Program (ODP) was to obtain data about the response of global climate change during the Neogene. Eleven sites were drilled on three lithospheric plates of the eastern Pacific: Cocos, Nazca, and Pacific. The western transect sites, on the Pacific Plate, are Sites $848,849,850,851,852$, 853 , and 854 . The eastern transect sites included Sites 844 and 845 , drilled in the Cocos Plate, and Sites 846 and 847, drilled on the Nazca Plate (Fig. 1; Mayer, Pisias, Janecek, et al., 1992).

Sites 844 through 852 were logged with the geochemical tool (GLT), which measures the major elements of a formation at intervals of $0.1524 \mathrm{~m}$. The GLT measurements provide continuous, in-situ chemical measurements of the rock that are not affected by incomplete core recovery or core expansion, which are problems that core-based studies often encounter.

This report describes the basic principles of the GLT, outlines the post-cruise processing techniques, and briefly compares geochemical $\log$ values with lithologic core descriptions and available core measurements. The report focuses on presenting the data and explaining how they were derived.

\section{GEOCHEMICAL TOOL STRING}

The geochemical logging tool string (GLT) consists of four tool components: the natural gamma-ray tool (NGT), the compensated neutron tool (CNT), the aluminum activation clay tool (AACT), and the gamma-ray spectrometry tool (GST) (GLT, NGT, CNT, AACT, and GST are trademarks of Schlumberger; Fig. 2). The combination of the tool components uses three separate modes of gamma-ray spectroscopy for a comprehensive elemental analysis of the formation. The NGT, located at the top of the tool string, measures the naturally occurring radionuclides, thorium (Th), uranium (U), and potassium $(\mathrm{K})$ before the formation is irradiated by the nuclear sources contained in the tools below. The CNT, located below the

' Pisias, N.G., Mayer, L.A., Janecek, T.R., Palmer-Julson, A., and van Andel, T.H. (Eds.), 1995. Proc. ODP, Sci. Results, 138: College Station, TX (Ocean Drilling Program)

${ }^{2}$ Borehole Research Group, Lamont-Doherty Earth Observatory, Columbia University, Palisades, NY 10964, U.S.A.

${ }^{3}$ Hawaii Institute of Geophysics, University of Hawaii, Honolulu, HI 96822, U.S.A.
NGT, carries a low-energy californium-252 $\left({ }^{252} \mathrm{Cf}\right)$ neutron source to activate the $\mathrm{Al}$ atoms in the formation. The AACT, a modified NGT, is located below the ${ }^{252} \mathrm{Cf}$ source and measures the activated gamma rays in the formation. By combining the AACT measurement with the previous NGT measurement, the background radiation is eliminated and a reading of formation $\mathrm{Al}$ is obtained (Scott and Smith, 1973). The GST, at the base of the string, carries a pulsed neutron generator to induce prompt-capture gamma-ray reactions in the borehole and formation and an $\mathrm{NaI}(\mathrm{Tl})$ scintillation detector to measure the energy spectrum of gamma rays generated by the neutron capture reactions. Because each of the elements in the formation is characterized by a unique spectral signature in the cross-section, it is possible to derive the contribution (or yield) of each of the major elements silicon ( $\mathrm{Si}$ ), iron $(\mathrm{Fe})$, calcium $(\mathrm{Ca})$, titanium (Ti), sulfur $(\mathrm{S})$, gadolinium (Gd), and potassium $(\mathrm{K})$ from the measured spectrum; then, in turn, to estimate the relative abundance in the formation of each element above by combining with the elemental concentrations from the NGT and AACT. The GST also measures the hydrogen $(\mathrm{H})$ and chlorine (Cl) in the borehole and formation, but these elements are not used for determining rock geochemistry.

The only major rock-forming elements not measured by the GST are magnesium $(\mathrm{Mg})$ and sodium $(\mathrm{Na})$; the neutron-capture cross sections of these elements are too small relative to their typical abundance to be detected by the GST. A rough estimate of $\mathrm{Mg}+\mathrm{Na}$ can be made by using the photoelectric factor (PEF), measured by the lithodensity tool. Further explanation of this technique is found in Hertzog et al. (1989). This measured PEF is compared with a calculated PEF (a summation of the PEF from all of the measured elements). The separation between the measured and calculated PEF is, in theory, attributable to any element left over in the formation (i.e., $\mathrm{Mg}$ and $\mathrm{Na}$ ). The $\mathrm{Mg}$ calculation was not attempted for this leg because including it in the normalization with the other elements induces noise into all other elements, which proves to be erroneous in ODP wells (Pratson et al., 1993). Generally, $\mathrm{MgO}+\mathrm{Na}_{2} \mathrm{O}$ values from core data are included in the normalization step of the processing. During Leg 138, values from core measurements were included in the normalization step of the processing of logging data from Holes $844 \mathrm{~B}, 850 \mathrm{~B}$, and $851 \mathrm{~B}$. This normalization step was not performed for all other holes during the Leg 138 processing because the core data were unavailable or the measurement of $\mathrm{MgO}+\mathrm{Na}_{2} \mathrm{O}$ was insignificant. This is explained further in Step 5 of the data reduction section below. 


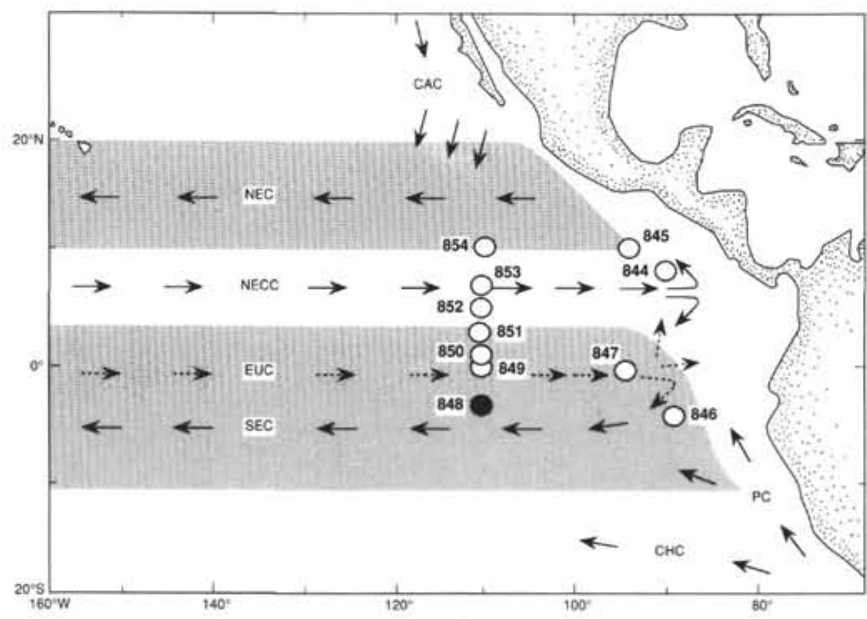

Figure 1. Generalized circulation system of the eastern equatorial Pacific Ocean. Surface current shown as solid arrows, subsurface current as dashed arrows: $\mathrm{CAC}=$ California Current; $\mathrm{NEC}=$ North Equatorial Current; NECC $=$ North Equatorial Countercurrent; EUC $=$ Equatorial Undercurrent; $\mathrm{SEC}=$ South Equatorial Current; $\mathrm{PC}=$ Peru Current; and $\mathrm{CHC}=$ Chile Current. Shaded areas illustrate general latitudinal extent of the SEC and NEC. Locations of Sites 844 through 854 of Leg 138 also are shown (after Mayer, Pisias, Janecek, et al., 1992).

\section{DATA REDUCTION}

The well-logging data from the Schlumberger tools are transmitted digitally up a wireline and are recorded and processed on the JOIDES Resolution in the Schlumberger Cyber Service Unit (CSU). The results from the CSU are made available as "field logs" for initial shipboard interpretation. Subsequent reprocessing is necessary to correct the data for the effects of fluids added to the well, logging speed, and drill-pipe interference. Processing of the spectrometry data is required to transform the relative elemental yields into oxide weight fractions.

This processing is performed with a set of log-interpretation programs written by Schlumberger, which were modified to account for the lithologies and hole conditions encountered in ODP holes. The steps are summarized below.

Step 1. Reconstruction of relative elemental yields from recorded spectral data.

This first processing step compares the measured spectra from the gamma-ray spectrometry tool with a series of standard spectra to determine the relative contribution (or yield) of each element. Each standard approximates the spectrum of each element and is combined at each depth with the recorded spectrum in a weighted, least-squares inversion to determine the relative elemental yields. Six elemental standards $(\mathrm{Si}, \mathrm{Fe}, \mathrm{Ca}, \mathrm{S}, \mathrm{Cl}$, and $\mathrm{H})$ are used to produce the shipboard yields, but three additional standards ( $\mathrm{Ti}, \mathrm{Gd}$, and $\mathrm{K}$ ) can be included in the post-cruise processing to improve the fit of the spectral standards to the measured spectra (Grau and Schweitzer, 1989). Although Ti, Gd, and $\mathrm{K}$ often appear in the formation in very low concentrations, they can make a large contribution to the measured spectra because they have large neutron-capture cross sections. For example, the capture cross section of $\mathrm{Gd}$ is 49,000 barns, whereas that of $\mathrm{Si}$ is 0.16 barns (Hertzog et al., 1989). Therefore, including Gd is necessary when calculating the best fit of the standard spectra to the measured spectra.

The spectral analysis was performed using the spectral standards for $\mathrm{H}, \mathrm{Si}, \mathrm{Ca}, \mathrm{Cl}, \mathrm{Fe}, \mathrm{Ti}$, and $\mathrm{Gd}$ for Holes 845B, 846B, 847B, 848B, $849 \mathrm{~B}, 850 \mathrm{~B}, 851 \mathrm{~B}$, and $852 \mathrm{D}$. The spectral standards for $\mathrm{S}$ and $\mathrm{K}$ were not used, because these elements exist in concentrations below the resolution of the tool, and the inclusion of $\mathrm{S}$ and $\mathrm{K}$ were found to increase the noise level significantly of all the other yields. For Hole 844B, spectral analysis using the standards $\mathrm{H}, \mathrm{Si}, \mathrm{Ca}, \mathrm{Fe}$, and $\mathrm{Gd}$ was

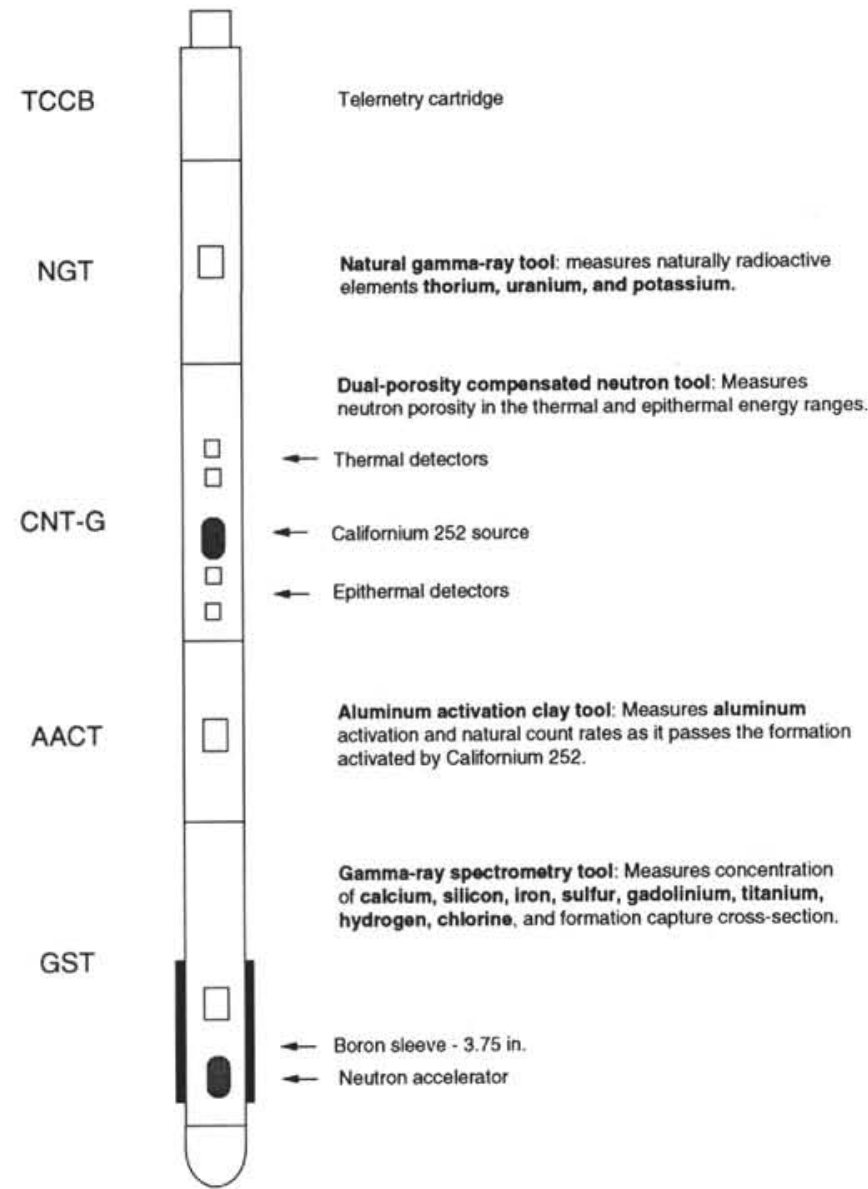

Figure 2. Schematic drawing of the Schlumberger geochemical logging tool string used in the Ocean Drilling Program.

performed and the elements $\mathrm{S}, \mathrm{K}$, and $\mathrm{Ti}$ were not used because the concentrations of these elements are below the resolution of the tool and add noise to all other yields. A straight, seven-point ( $3.5 \mathrm{ft}, 1.066$ $\mathrm{m})$ smoothing filter was applied to all the yields to reduce the noise in the data during this reconstruction step. An additional 10-point (5 $\mathrm{ft}, 1.523 \mathrm{~m}$ ) smoothing filter was applied to Hole $846 \mathrm{~B}$, and an additional five-point $(2.5 \mathrm{ft}, 0.76 \mathrm{~m})$ smoothing filter was applied to Holes $847 \mathrm{~B}, 849 \mathrm{~B}, 850 \mathrm{~B}$, and $851 \mathrm{~B}$ to reduce the noise level further in the normalization factor (explained in Step 5), which affects the overall character of the final elemental yields.

Step 2. Depth shifting.

Geochemical processing involves the integration of data from the different tool strings; consequently, it is important that all the data are depth correlated to one reference logging run. The NGT, run on each of the logging tool strings, provides a spectral gamma-ray curve with which to correlate each of the logging runs. A reference run is chosen on the basis of low cable tension (the logging run with the least amount of cable sticking) and high cable speed (tools run at faster speeds are less likely to stick and are less susceptible to data degradation caused by ship heave). The depth-shifting procedure involves selecting several reference points where log characters are similar and then invoking a program that stretches or squeezes sections of the matching logging run to fit the reference logging run.

The reference run chosen for Holes $844 \mathrm{~B}, 847 \mathrm{~B}, 849 \mathrm{~B}, 850 \mathrm{~B}$, and $851 \mathrm{~B}$ is the formation microscanner (FMS). Correlating the results of the runs to core-based GRAPE data, Holes $849 \mathrm{~B}$ and $850 \mathrm{~B}$ were then shifted up $1.83 \mathrm{~m}$ and $0.91 \mathrm{~m}$, respectively. The GLT was the chosen reference run for Hole $845 \mathrm{~B}$; therefore, no depth shifting was necessary. The main pass of the quad-combo, which is a logging string that 
includes a resistivity tool (DITE), a sonic tool (LSS), a density tool (HLDT), a natural gamma-ray tool (NGT), and a temperature tool (TLT), was chosen as the reference run in Hole 846B. No depthshifting in reference to logs was performed in Holes 848B and 852D because the GLT was the only log run in these holes. However, Hole $852 \mathrm{D}$ was shifted up $2.1 \mathrm{~m}$ to match an identified calcium carbonate peak seen in core studies (Shipboard Scientific Party, 1992i).

Step 3. Calculation of total radioactivity and Th, U, and K concentrations.

The third processing routine calculates the total natural gamma radiation in the formation as well as concentrations of Th, $\mathrm{U}$, and $\mathrm{K}$, using the counts in five spectral windows from the natural gamma-ray tool (Lock and Hoyer, 1971). This routine resembles shipboard processing; however, the results are improved during post-cruise processing by including corrections for hole-size changes and temperature variations. A Kalman filtering process (Ruckebusch, 1983 ) is used in the CSU processing at sea to minimize the statistical uncertainties in the logs, which can otherwise create erroneous negative values and anti-correlation (especially between $\mathrm{Th}$ and $\mathrm{U}$ ). An alpha filter was introduced more recently and is now recommended by Schlumberger for shore-based processing. This filter strongly smoothes the raw spectral counts but keeps the total gamma-ray curve unsmoothed before calculating out the Th, U, and K (Charles Flaum, pers. comm., 1988). The outputs of this program are $\mathrm{K}$ (wet wt\%), $\mathrm{U}$ (ppm), and Th (ppm), as well as total gamma-ray and computed gamma-ray (total gamma ray minus $\mathrm{U}$ contribution) curves.

Step 4. Calculation of Al concentration.

The fourth processing routine calculates the concentration of $\mathrm{Al}$ in the formation using four energy windows recorded with the AACT. During this step, corrections are made for natural radioactivity, borehole-fluid neutron-capture cross section, formation neutron-capture cross section, formation slowing-down length, and borehole size. Porosity and density logs are needed to convert the wet-weight percentages of $\mathrm{K}$ and $\mathrm{Al}$ curves to dry-weight percentages.

A porosity log is recorded on the geochemical tool string; however, it can be used only as a qualitative measurement, since it carries a ${ }^{252} \mathrm{Cf}$ source, rather than the calibrated americium-beryllium source needed to measure quantitatively. When the density log compares well with shipboard density core measurements, a porosity curve is derived from the density log using the equation,

$$
\phi_{t}=\left(\rho_{m}-\rho_{b}\right) /\left(\rho_{m}-\rho_{f}\right),
$$

where

$$
\begin{aligned}
& \phi_{t}=\text { percentage of porosity, } \\
& \rho_{m}=\text { matrix density } \\
& \quad(\text { a constant value or } \log \text { matrix density can be used in } \\
& \left.\mathrm{g} / \mathrm{cm}^{3}\right) \text {, } \\
& \rho_{b}=\text { bulk density from the } \log \text { in } \mathrm{g} / \mathrm{cm}^{3}, \text { and } \\
& \rho_{f}=\text { density of fluid }=1.05 \mathrm{~g} / \mathrm{cm}^{3} .
\end{aligned}
$$

An alternative method of calculating porosity from the logging data in high-porosity ranges is the neutron-derived method which uses the corrected far thermal counts (CFTC) measured with the compensated neutron tool (CNT) run with the GLT string using the ${ }^{252} \mathrm{Cf}$ source. The CNT detects far and near thermal neutrons by counting a combination of the slowing down length and the diffusion length of the neutrons. Far and near designations are determined by the distance of the detectors from the ${ }^{252} \mathrm{Cf}$ source. The thermal neutron detectors are highly efficient which results in good statistical behavior as well as being sensitive to the rock-matrix composition. The far detectors have lower counting rates, which lead to larger statistical uncertainties; however, the far thermal counts exhibit better porosity sensitivity than the near thermal counts. A porosity calibration of the neutron $\log$ was obtained by using the core data from Hole $846 \mathrm{~B}$ of this leg (Truax, 1992). Many models were investigated by Truax; however, for the purposes of calculating porosity for reprocessing of the geochemical data, the far thermal counts were used, which resulted in only $3 \%$ statistical uncertainty. After the CFTC data were smoothed by a graduated nine-level filter, the equation below was applied,

$$
\phi_{t}=76248 \cdot\left(\text { CFTC }^{-1.6052}\right)+36.87 \text {, }
$$

where

$$
\begin{aligned}
& C F T C=C F T C \cdot \text { GAIN, } \\
& (1 / \text { GAIN })=\mathrm{e}^{(-t / 391)}, \\
& \phi_{t}=\text { percentage of porosity, } \\
& \text { CFTC }=\text { calculated corrected far thermal counts, } \\
& \text { CFTC }=\text { measured corrected far thermal counts, } \\
& \text { GAIN = time function of source, and } \\
& t=\text { time in days from calibration data; } \\
& \text { the GLT logging date of Hole } 846 \mathrm{~B}(5 / 23 / 91) .
\end{aligned}
$$

Both methods for calculating porosity are used when the data are available. The chosen porosity curve is the one that best compares to the core porosity measurements. The porosity curve used for Holes $844 \mathrm{~B}, 849 \mathrm{~B}$, and $851 \mathrm{~B}$ was calculated using the density method that used the bulk density from the log and the matrix density from interpolated core data. For Hole 845B, an interpolated core porosity curve was used because the comparison of the calculated porosity to core porosity was poor. The porosity curve using the CFTC calculation compared better to core data for Holes 846B, 847B, 850B, and 852D; therefore, the neutron-derived method of calculating porosity was used. In Hole $848 \mathrm{~B}$, the porosity curve was derived by interpolating the core data because only the geochemical log was run and CFTC data were not recorded. Generally, for this leg, the porosity calculated from the neutron-derived method compared better to the core measured porosity than the density-porosity calculation method. Therefore, for all holes for which the CNT data were recorded, the neutron-derived method of porosity was used in the reprocessing of the GLT data.

A correction is also made for $\mathrm{Si}$ interference with $\mathrm{Al}$; the ${ }^{252} \mathrm{Cf}$ source activates the $\mathrm{Si}$, producing the aluminum isotope ${ }^{28} \mathrm{Al}$ (Hertzog et al., 1989). The program uses the $\mathrm{Si}$ yield from the gamma-ray spectrometry tool to determine the Si background correction. The program calculates dry-weight percentages of $\mathrm{Al}$ and $\mathrm{K}$, which are used in the calculation and normalization of the remaining elements.

Step 5. Normalization of elemental yields from the GST to calculate the elemental weight fractions.

Relative concentrations of the GST-derived elemental yields can be determined by dividing each elemental yield by a relative spectral sensitivity factor, $S_{i}$. These factors are constants, which can be measured in the laboratory and are principally related to the thermal neutron-capture cross sections and the gamma-ray production and detection probabilities of the element (Hertzog et al., 1989). The relative elemental concentrations are related to the desired absolute concentrations by a depth-dependent normalization factor, $F$, as defined by the relationship

$$
W t_{i}=F Y_{i} / S_{i},
$$

where

$$
\begin{aligned}
& W t_{i}=\text { absolute elemental concentration, } \\
& Y_{i}=\text { relative elemental yield, } \\
& S_{i}=\text { relative spectral sensitivity factor, and } \\
& F=\text { depth-dependent normalization factor. }
\end{aligned}
$$

The normalization factor is calculated based on the assumption that the sum of all the elemental weight fractions is $100 \%$. The closure model accounts for carbon and oxygen, which are not measured by this tool string, by approximating their amounts in combination with each of the measurable elements as a single carbonate or oxide factor. The dry-weight percentages of $\mathrm{Al}$ and $\mathrm{K}$ are normalized with the reconstructed elemental yields to determine $F$ at each depth interval with the following equation: 


$$
F\left(\Sigma_{i} X_{i} Y_{i} / S_{i}\right)+X_{K} W t_{K}+X_{A l} W t_{A l}=100,
$$

where

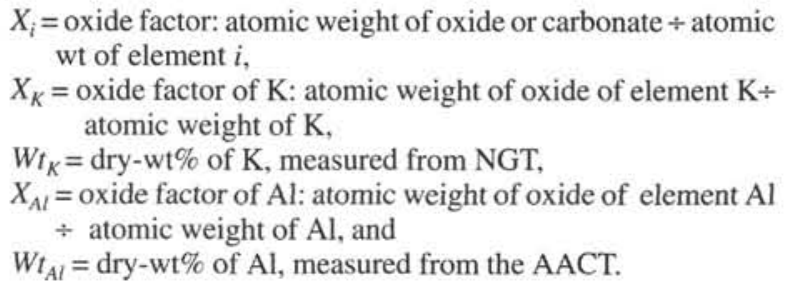

The value $X_{i}$ accounts for the $\mathrm{C}$ and $\mathrm{O}$ associated with each element. Table 1 lists the oxide factors used in this calculation. All of the measured elements associate with $\mathrm{C}$ and $\mathrm{O}$ in a constant ratio in these lithologies except for $\mathrm{Ca}$, which associates with $\mathrm{C}$ and $\mathrm{O}$ in one of two ways: $\mathrm{CaCO}_{3}$ or $\mathrm{CaO}$ (Table 1). To convert the measured yields to elements, a dominant oxide factor must be assumed at every depth level. A routine that combines both these oxide factors is implemented here, as suggested by James Grau at Schlumberger-Doll (pers. comm., 1992). When the elemental form of $\mathrm{Ca}$ is less than $6 \%, \mathrm{CaO}$ is assumed and an oxide factor of 1.399 is used. When the elemental form of $\mathrm{Ca}$ is greater than $12 \%, \mathrm{CaCO}_{3}$ is assumed and an oxide factor of 2.497 is used. If the elemental form of $\mathrm{Ca}$ falls between $6 \%$ and $12 \%$, both forms are assumed to be present and the oxide factor is linearly interpolated between 1.399 and 2.497 .

The parameters of $6 \%$ and $12 \%$ were chosen according to observations of the natural occurrence of $\mathrm{Ca}$. $\mathrm{CaO}$ is not likely to occur in quantities greater than $12 \%$. When $\mathrm{Ca}$ is less than $6 \%$, even if it is $\mathrm{CaCO}_{3}$, the error will be small using 1.399 as the oxide factor instead of 2.497. The linear interpolation is done to provide a smooth transition from $\mathrm{CaO}$ to $\mathrm{CaCO}_{3}$ and to prevent any erroneous chemical changes on the final processed logs. This procedure for calculating $\mathrm{Ca}$ is accurate in most cases and minimizes the error when the model is not exactly correct.

The $\mathrm{Mg}$ and $\mathrm{Na}$ content curves cannot be calculated from the logs, because the neutron-capture cross sections of these elements are too small relative to their typical abundance for detection by the tool string; therefore, available core information is included. $\mathrm{Mg}$ and $\mathrm{Na}$ represent up to $8.47 \%$ of the rock in Hole 844B (Shipboard Scientific Party, 1992a). A constant value of $3.94 \% \mathrm{MgO}+\mathrm{Na}_{2} \mathrm{O}$ was used in the normalization of Hole 844B, which was derived from the average measured core values. All other holes including Holes $845 \mathrm{~B}, 846 \mathrm{~B}$, $847 \mathrm{~B}, 848 \mathrm{~B}, 849 \mathrm{~B}, 850 \mathrm{~B}, 851 \mathrm{~B}$, and $852 \mathrm{D}$, had insufficient or insignificant data to use in this normalization process; therefore, this process was not performed.

Step 6. Calculation of oxide percentages.

The final routine converts the elemental weight percentages into oxide/carbonate percentages by multiplying each by its associated oxide factor, as shown in Table 1.

Step 7. Calculation of error logs.

The calculated statistical uncertainty of each element is calculated from each of the elements measured with the GST and NGT (Grau et al., 1990; Schweitzer et al., 1988). This error is strongly related to the normalization factor, which is calculated at each depth (Eq. 3). The normalization factor is displayed to the right of the logs. A lower normalization factor represents better counting statistics and higher quality data.

\section{COMPARISON OF GEOCHEMICAL LOGS TO CORE}

\section{Site 844}

The primary objective of Site 844 was to obtain a continuous Neogene record of the Guatemala Basin of the eastern equatorial Pacific Costa Rica Dome and the equatorial current regime. This site is located within the eastward-flowing North Equatorial Countercurrent and in the area of the Costa Rica Dome (Shipboard Scientific
Table 1. Oxide factors used for normalizing elements to $100 \%$ and for converting elements to oxides.

\begin{tabular}{lll}
\hline \multicolumn{1}{c}{ Element } & \multicolumn{1}{c}{ Oxide/carbonate } & \multicolumn{1}{c}{$\begin{array}{c}\text { Conversion } \\
\text { factor }\end{array}$} \\
\hline $\mathrm{Si}$ & $\mathrm{SiO}_{2}$ & 2.139 \\
$\mathrm{Ca}<6 \%$ & $\mathrm{CaO}^{2}$ & 1.399 \\
$6 \%<\mathrm{Ca}<12 \%$ & $\mathrm{CaO}$ and $\mathrm{CaCO}_{3}$ & $\begin{array}{l}1.399-2.497 \\
\text { linearly interpolated }\end{array}$ \\
$\mathrm{Ca}>12 \%$ & $\mathrm{CaCO}_{3}$ & 2.497 \\
$\mathrm{Fe}$ & $\mathrm{FeO}^{+}$ & 1.358 \\
$\mathrm{~K}$ & $\mathrm{~K}_{2}$ & 1.205 \\
$\mathrm{Ti}$ & $\mathrm{TiO}_{2}$ & 1.668 \\
$\mathrm{Al}$ & $\mathrm{Al}_{2} \mathrm{O}_{3}$ & 1.889 \\
\hline
\end{tabular}

Party, 1992a). Site 844 encountered sediments that were described as two lithologic units. Unit I (0-67.7 mbsf) consists of pliocenepleistocene clay-rich biogenic silica ooze with minimal carbonate. Unit II (67.7-290.8 mbsf), mostly carbonates, consists of nannofossil ooze with varying amounts of other microfossil groups (Shipboard Scientific Party, 1992a). The portion of the logging data recorded through pipe, above $42 \mathrm{mbsf}$, was not processed because of the low percentage of readings; hence, any lithologic interpretation of logcharacter change would be questionable. The logging data $30 \mathrm{~m}$ from the top of the open-hole section is also questionable because the drill pipe was pulled while logging from 72 to $42 \mathrm{mbsf}$, at which depth the log was pulled through the pipe. Therefore, only Unit II is compared to core measurements.

The processed natural gamma-ray curves at Hole 844B are shown in Figure 3. The processed NGT curves are the from geochemical logging tool string. Figure 4 displays the oxide-weight fractions estimated from the logs at Hole $844 \mathrm{~B}$, along with calculated statistical uncertainties of each element (Grau et al., 1990; Schweitzer et al., 1988). A log of the Ca oxide factor used is displayed to the right of the normalization factor. Available core measurements of $\mathrm{CaCO}_{3}$ and $\mathrm{XRF}$ major elemental analyses are displayed as solid diamonds and solid circles, respectively, for comparison with the oxide-weight fractions derived from the logging data. To get a complete section of the potassium curve, it was necessary to splice the bottom of the potassium curve from the quad-combo at $284.7 \mathrm{mbsf}$ to the GLT potassium curve. Core measurements were taken from four holes at Site 844 ; Holes $844 \mathrm{~A}, 844 \mathrm{~B}$, and $844 \mathrm{C}$ contributed to the XRF, $\mathrm{CaCO}_{3}$, and physical-properties data, and Hole $844 \mathrm{D}$ core contributed to the $\mathrm{CaCO}_{3}$ and the physical-properties data.

The $\mathrm{CaCO}_{3}$-core agreement is good throughout the sediment section of Unit II. The XRF-log agreement is uncertain due to the lack of a good sampling of XRF core data. In addition to the lack of data, the XRF core measurements were taken within a few meters of the pipe and may compare poorly to logging data because of the interference from the pipe effect on the log measurements or the operation of logging while pulling into the pipe.

\section{Site 845}

The primary objectives of Site 845 were to calibrate the equatorial biostratigraphies to the paleomagnetic time scale, examine the late Neogene history of the North Equatorial Current, and determine the age of the basement in the Guatemala Basin. This site is located in a divergence-driven, upwelling zone beneath the North Equatorial Current, near the boundary between the North Equatorial Current and the eastward-flowing North Equatorial Countercurrent (Shipboard Scientific Party, 1992b; Fig. 1). Site 845 encountered sediments that were described as two lithologic units. The section of the logging data recorded through pipe, above $51.3 \mathrm{mbsf}$, was not processed because of the low percentage of readings; hence, any lithologic interpretation of log character change would be questionable. Unit I (0-136.2 mbsf), from pleistocene to late miocene in age, is dominantly diatom clay and radiolarian clay with one isolated interval of carbonate sediments. Unit I is separated into three subunit intervals, which are not distin- 

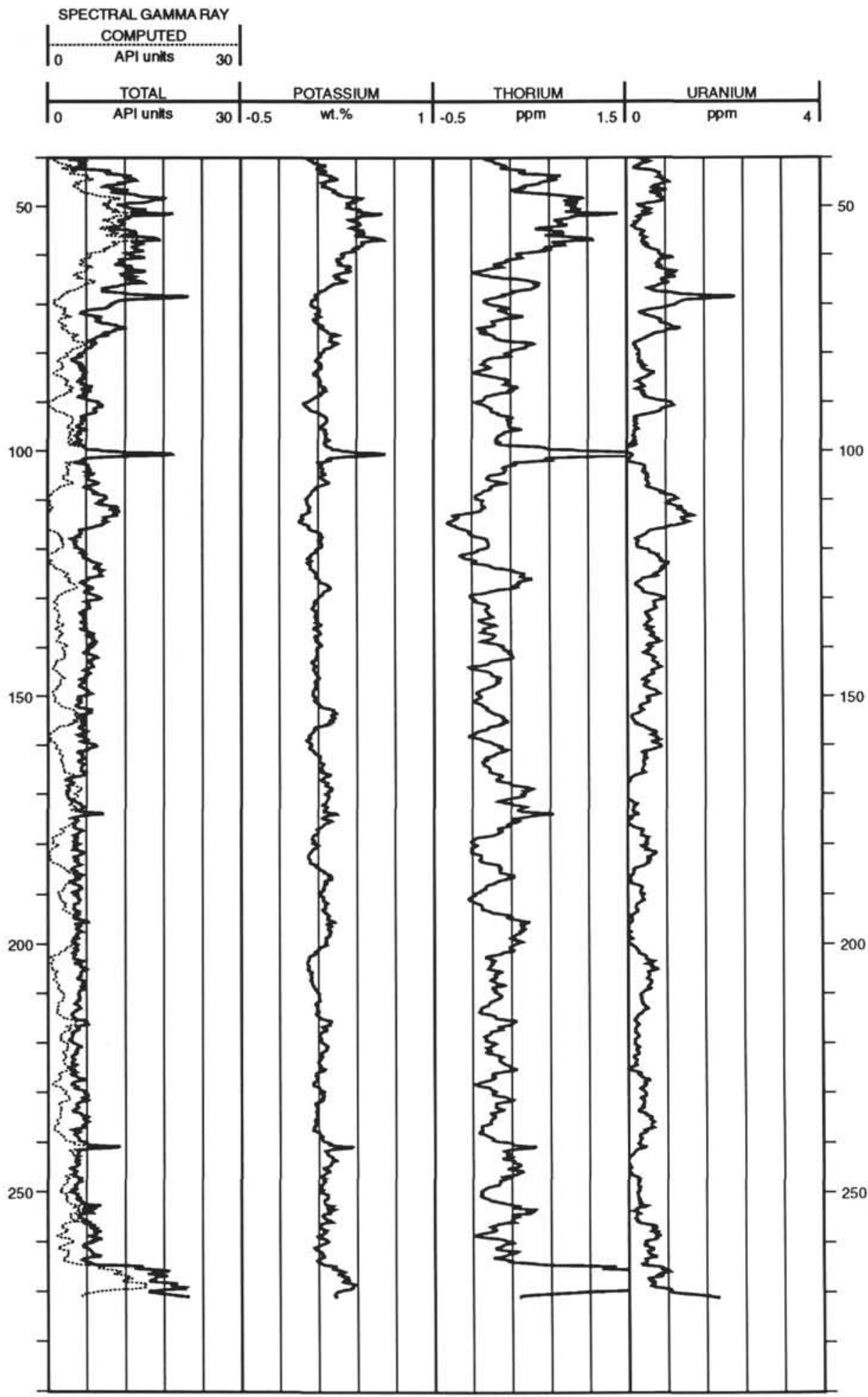

Figure 3. Processed natural gamma-ray data, Hole 844B.

guished on the geochemical logs. Unit II (136.2-202.6 mbsf), from middle to late miocene in age, consists of mostly nannofossil ooze with a distinct transitional siliceous/carbonate interval. Subunit IIA (136.2-149.4 mbsf) comprises of a transitional sequence, evident in the aluminum and potassium curves, between the siliceous microfossil and clay-rich sediments. Subunits IIB (149.4-202.6 mbsf) and IIC (202.6-291.4 mbsf) are not distinguished on the geochemical logs (Shipboard Scientific Party, 1992b).
The processed natural gamma-ray curves from Hole $845 \mathrm{~B}$ are shown in Figure 5. The processed NGT curves are from the geochemical logging tool string. To get a complete section of the K curve, it was necessary to splice the bottom of the K curve from the second FMS run at 273.9 mbsf to the GLT K curve. Figure 6 displays the oxideweight fractions estimated from the logs at Hole $845 \mathrm{~B}$, along with calculated statistical uncertainties of each element with a log of the $\mathrm{Ca}$ oxide factor. An additional five-point smoothing was necessary for the 

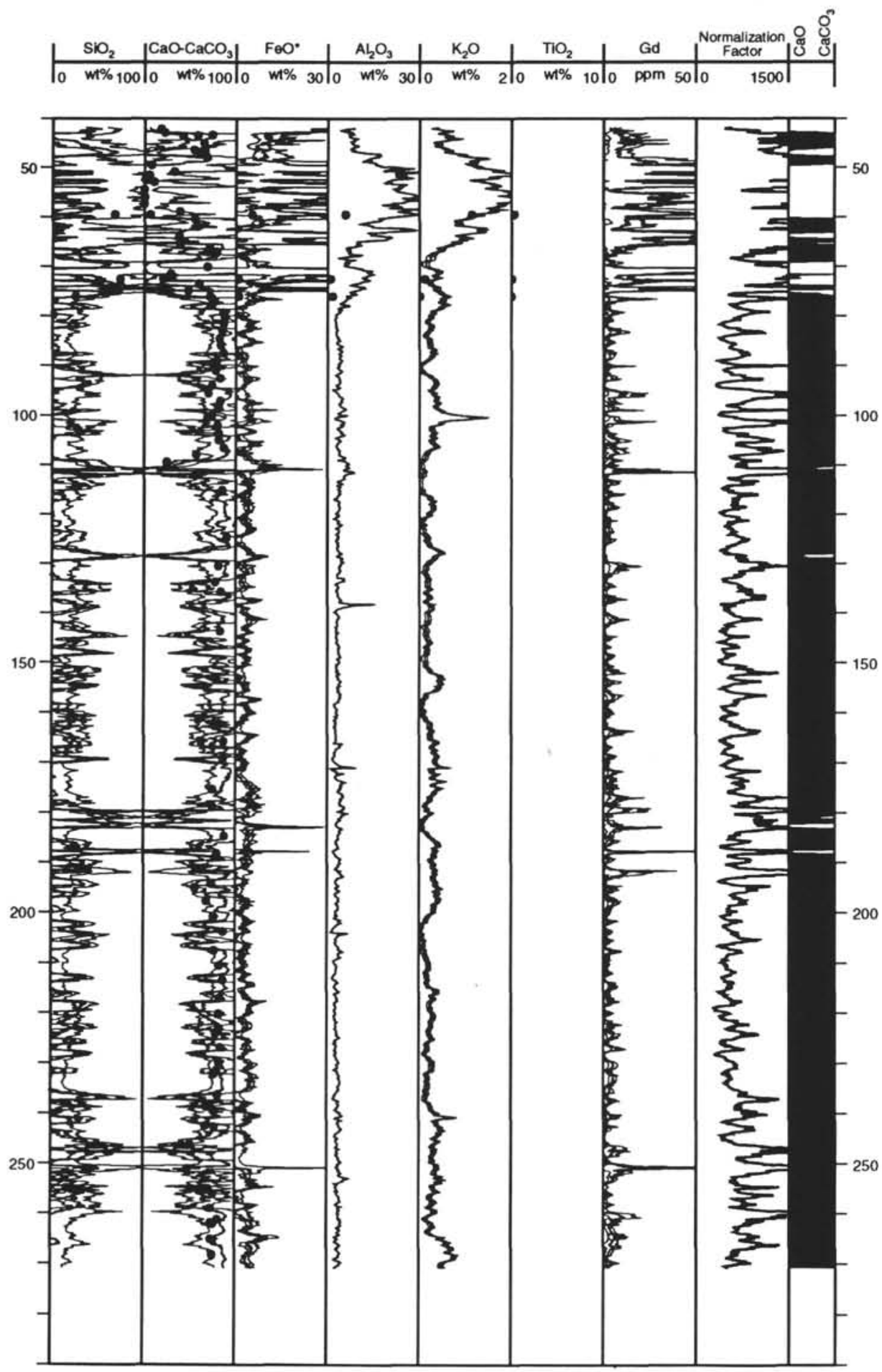

Figure 4. Estimates of calcium carbonate and major oxide-weight fractions from geochemical logs, Hole 844B. Solid diamonds and solid circles represent $\mathrm{CaCO}_{3}$ and XRF measurements, respectively (Shipboard Scientific Party, 1992a). The Ti readings were below the resolution of the tool, therefore, were not determined.

elemental yields and a 10-point smoothing was needed for the Fact curve (normalization factor) to remove noise from the data. A discrimination program was also applied to the Fact curve to eliminate all values higher than 1200 , which were inducing erroneous noise in the final data. Both the $\mathrm{Al}$ and $\mathrm{K}$ curves were extrapolated to process the bottom $18 \mathrm{~m}$ of the GLT data. The Al curve has a noticeable increase at $64 \mathrm{mbsf}$ that cannot be explained by a change in the lithology (excellent core recovery) nor mechanical configuration, but yet is confirmed by a similar increase seen on the $\mathrm{K}$ curve (both clay-related curves). The GLT data are poor from this hole because of extremely high porosity values that cause the tool readings attributable to the rock to be very low. This is indicated by the extremely high Fact values. To explain the high Fact readings, we included two additional columns in Figure 6. The column adjacent to the variable $\mathrm{Ca}$ oxide factor curve is the summation curve. This curve represents the percentage of the tool readings from the rock of all the rock-forming 

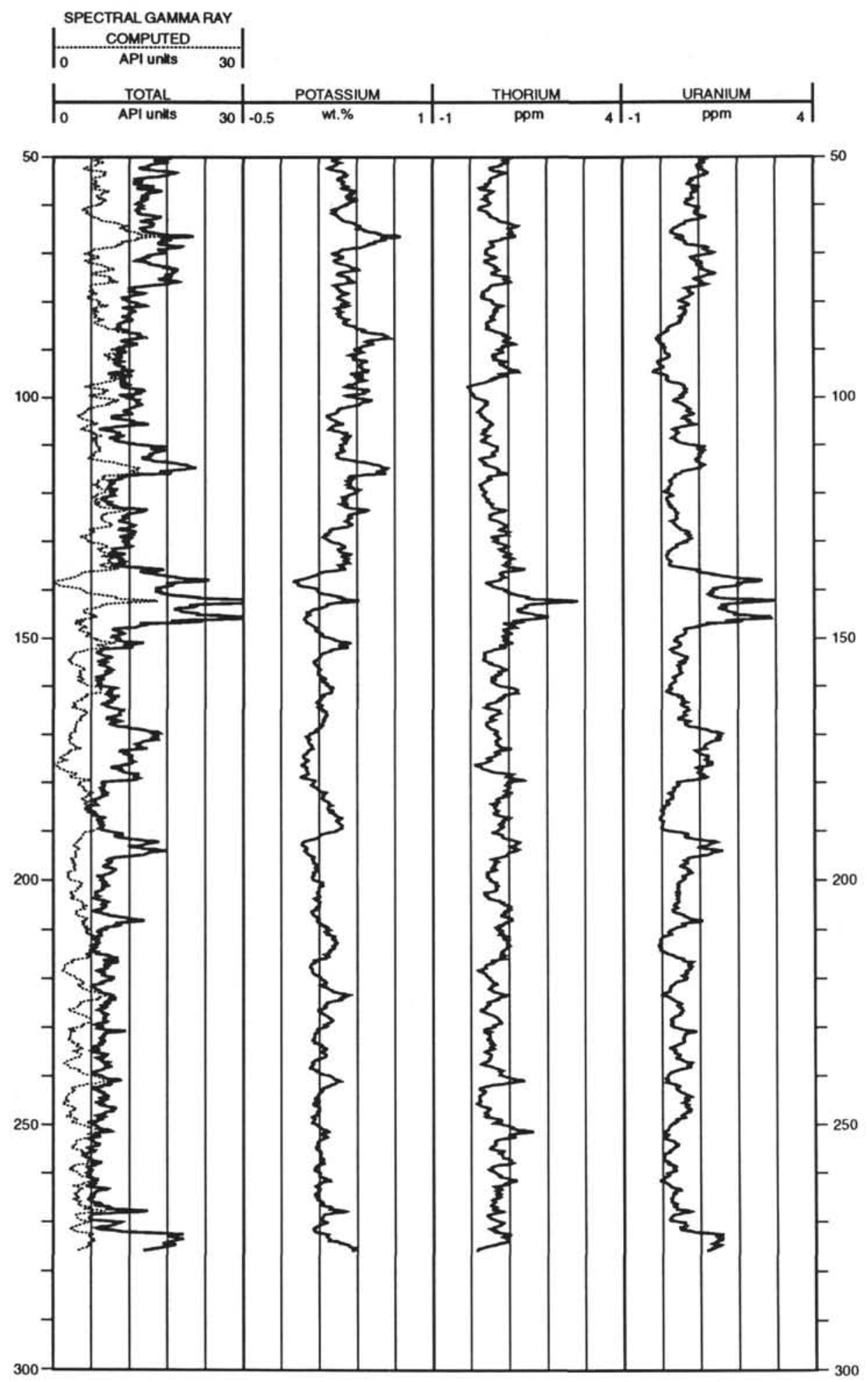

Figure 5. Processed natural gamma-ray data, Hole 845B.

yields, increasing to the left. As seen in the log, the tool reads close to $100 \%$ from the rock in the lower sections, yet barely reads $20 \%$ from the rock in the upper sections. The far-right column displays the porosity curve used in these calculations, which reveal the extremely high porosity values throughout this hole. Available core measurements of $\mathrm{CaCO}_{3}$ and XRF major elemental analyses are displayed as solid diamonds and solid circles, respectively. Site 845 core measurements were taken from three holes. Cores from Holes $845 \mathrm{~B}$ and $845 \mathrm{C}$ contributed to the physical-properties data. Holes $845 \mathrm{~A}$ and $845 \mathrm{~B}$ cores contributed to the XRF data and Hole $846 \mathrm{~A}$ contributed to the $\mathrm{CaCO}_{3}$ data.

The $\mathrm{CaCO}_{3}$ log-core agreement is good throughout the sediment section of Units I and II. The comparison of XRF core measurements to logging measurements is good; however, only 14 samples were analyzed in three selected intervals of the hole, which may indicate a bias in the sampling. 

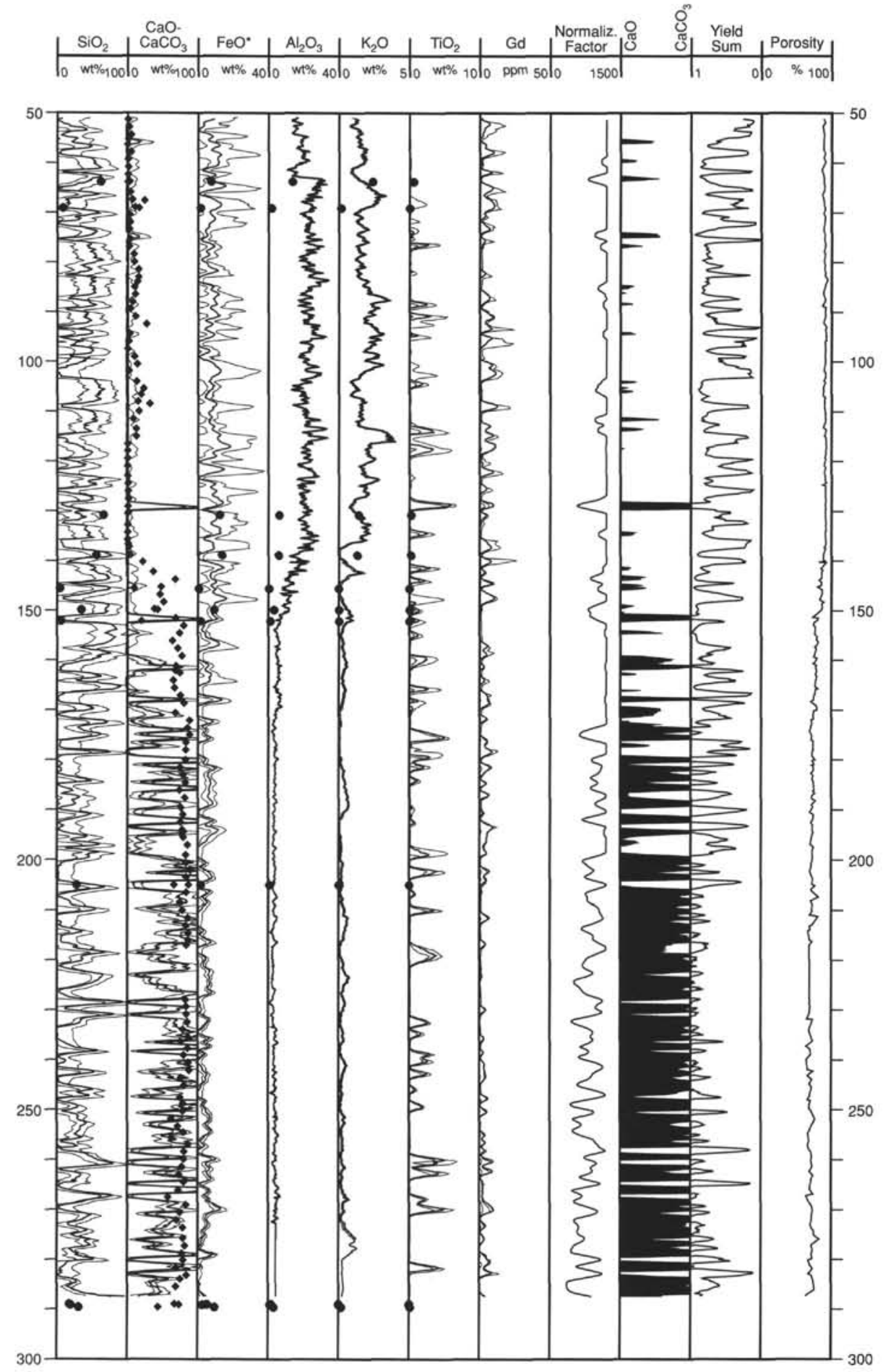

Figure 6. Estimates of calcium carbonate and major oxide-weight fractions from geochemical logs, Hole 845B. Solid diamonds and solid circles represent $\mathrm{CaCO}_{3}$ and XRF measurements, respectively (Shipboard Scientific Party, 1992b). The additional curves included are yield sum that displays the sum of the yields attributed to the rock, and porosity displays the associated high-porosity percentages in this rock.

\section{Site 846}

The primary objective of Site 846 was to obtain a historical record of the Peru Current and the eastern part of South Equatorial Current. This site is located on the southern limb of the Carnegie Ridge, 300 $\mathrm{km}$ due south of the Galapagos Islands (Shipboard Scientific Party, 1992c). In Site 846, sediments were encountered that were described as two lithologic units. The section of the logging data recorded through pipe, above 76 mbsf, was not processed because of the low percentage of readings; hence, any lithologic interpretation of logcharacter change would be questionable. Unit I (0-317 mbsf), middle Miocene to Pleistocene, alternates between mostly nannofossil car- 
bonate ooze and both diatom and radiolarian siliceous ooze and is described in two subunits. Subunit IA (0-262.7 mbsf) consists of banded sediment that encounters lithologies of nannofossil foraminifer diatom ooze, foraminifer diatom nannofossil ooze, and nannofossil ooze. Subunit IB (262.7-317.0 mbsf) consists predominantly of radiolarian-rich sediment, which includes clayey radiolarian diatom ooze, radiolarian diatom nannofossil ooze, and diatom nannofossil ooze with radiolarians. An overall lower $\mathrm{Ca}$ value is indicated by the logs in this subunit. A change in lithology is also suggested at $272 \mathrm{mbsf}$ by an increase in $\mathrm{FeO}^{*}, \mathrm{TiO}_{2}$, and $\mathrm{Gd}$. Unit II (317-419.2 mbsf) is middle to upper miocene and is described in two subunits. Subunit IIA (317-370.5 mbsf) consists of several cherty intervals with minor siliceous constituents. Subunit IIB (370.5-408.9 mbsf) is composed of nannofossil chalk with foraminifers (Shipboard Scientific Party, 1992c). Subunit IIA has an overall higher $\mathrm{SiO}_{2}$ value than Subunit IIB.

The processed natural gamma-ray curves from Hole $846 \mathrm{~B}$ are shown in Figure 7, processed from the geochemical logging tool string. Figure 8 displays the oxide-weight fractions estimated from the logs of Hole $846 \mathrm{~B}$, along with calculated statistical uncertainties of each element (Grau et al., 1990; Schweitzer et al., 1988). An additional five-point smoothing was necessary for the elemental yields and an 11-point smoothing for the Fact curve to remove noise from the data. A discrimination program also was applied to the Fact curve to eliminate all values higher than 1200 , which were inducing erroneous noise in the final data. The GLT data are poor from this hole because of extremely high porosity values, and the tool readings attributable to the rock are very low in some sections of the hole, as indicated by the high Fact values. To explain the high Fact readings, two additional columns are included in Figure 8 . The column adjacent to the variable $\mathrm{Ca}$ oxide factor curve is the summation curve of all of the rock-forming yields (increasing to the left). This summation curve represents the percentage of the readings of the tool from the rock. As seen on the log, the tool reads close to $100 \%$ from the rock through most of the hole and yet reads $0 \%$ from the rock in selected small intervals. The far-right column displays the porosity curve used in these calculations, which reveal high porosity values throughout this hole. Available core measurements of $\mathrm{CaCO}_{3}$ and XRF major elemental analyses are displayed as solid diamonds and solid circles, respectively. Site 846 core measurements were taken from three holes. Cores from Holes $846 \mathrm{~B}$ and $846 \mathrm{C}$ contributed to the physical-properties data. Holes $846 \mathrm{~A}$ and $846 \mathrm{~B}$ cores contributed to the XRF data, and Hole $846 \mathrm{~B}$ contributed to the $\mathrm{CaCO}_{3}$ data.

The $\mathrm{CaCO}_{3}$ core agreement is good throughout the sediment section of Units I and II. XRF core measurements were taken to characterize nonbiogenic sediments at a depth below the logged interval; therefore, no XRF core-log comparison was made.

\section{Site $\mathbf{8 4 7}$}

The primary objective of Site 847 was to obtain a historical record of the late Neogene paleoceanographic change within the equatorial divergence zone. This site is located west of the Galapagos Islands in the region of interaction between the shallow, eastward-flowing Equatorial Undercurrent and the westward-flowing surface South Equatorial Current (Shipboard Scientific Party, 1992d; Fig. 1). In Site 847 , sediments were encountered that were described as one lithologic unit. The portion of the logging data recorded through pipe, above 48 mbsf, was not processed because of the low percentage of readings; hence, any lithologic interpretation of log-character change would be questionable. The logging interval from 48 to $57 \mathrm{mbsf}$ was also excluded from reprocessing as a result of a section of bad data that we were unable to process. The pleistocene to upper miocene unit is a continuous sediment accumulation dominated by nannofossil ooze and diatom nannofossil ooze (Shipboard Scientific Party, 1992d).

The processed natural gamma-ray curves from Hole $847 \mathrm{~B}$, shown in Figure 9, are from the geochemical logging tool string. Figure 10 displays the oxide-weight fractions estimated from the logs at Hole
847B, along with calculated statistical uncertainties of each element. An additional five-point smoothing was necessary for the elemental yields to remove noise from the data. Available core measurements of $\mathrm{CaCO}_{3}$ are displayed as solid diamonds for comparison with the oxide weight fractions derived from the logging data. Site 847 core measurements were taken from three holes. Cores from Holes 847B and $847 \mathrm{C}$ contributed to the physical properties data. Holes $847 \mathrm{~A}$ and $847 \mathrm{~B}$ contributed to the $\mathrm{CaCO}_{3}$ data.

The $\mathrm{CaCO}_{3}$ core-log agreement is good throughout the sediment section. No XRF core measurements were taken at this site.

\section{Site 848}

The primary objective of Site 848 was to sample different elements of the equatorial circulation system in an area separated from the direct effects of the eastern boundary of the Pacific. This site is located beneath the westward-flowing South Equatorial Current on crust of the East Pacific Rise and is the southernmost site of the north-south transect. Site 848 encountered sediment described as one lithologic unit. Foraminifer nannofossil ooze dominates the entire sequence. The carbonate contents generally are greater than $60 \%$, and siliceous microfossils occur in minor amounts throughout the section. Diatom nannofossil ooze with radiolarians is also present in thin interbedded layers throughout the entire sequence. Nearing the bottom of the section, the influence of hydrothermal deposition near the ridge crest is determined by the increasing presence of sediments with a reddishbrown, semi-opaque oxide (Shipboard Scientific Party, 1992e).

The processed natural gamma-ray curves from Hole 848B (Fig. 11) are from the geochemical logging tool string, which was the only logging tool run in Hole 848B. During calibration of the AACT tool ${ }^{252} \mathrm{Cf}$ source, the formation in the hole from 83.2 to $63.2 \mathrm{mbsf}$ was ' activated. Because of the activation of this section, large spikes appear in the log readings; therefore, no processing was performed in this interval. Figure 12 displays the oxide-weight fractions estimated from the logs at Hole $848 \mathrm{~B}$, along with calculated statistical uncertainties of each element. Most of the data were recorded through pipe; the pipe depth is $88 \mathrm{mbsf}$. The iron curve was used to calibrate the through-pipe section with the openhole section to attempt to eliminate the pipe effect in the readings. The logging data recorded through pipe produce a low percentage of readings from the rock; hence, any lithologic interpretation of log-character change would be questionable. Both the $\mathrm{Al}_{2} \mathrm{O}_{3}$ and $\mathrm{K}_{2} \mathrm{O}$ curves were affected by the extrapolation performed on the NGT data and, as discussed above, were used to process the final oxides. Available core measurements of $\mathrm{CaCO}_{3}$ and XRF major elemental analyses are displayed as solid diamonds and solid circles, respectively, for comparison with the oxide-weight fractions derived from the logging data. Site 848 core measurements were taken from three holes. Cores from Holes $848 \mathrm{~B}$ and $848 \mathrm{C}$ contributed to the physical-properties data. Hole $848 \mathrm{C}$ core contributed to the XRF data, and Holes $848 \mathrm{~B}$ and $848 \mathrm{D}$ contributed to the $\mathrm{CaCO}_{3}$ data.

The $\mathrm{CaCO}_{3}$ and XRF core data compare poorly with the logged data due to the effects of the through-pipe logging. The pipe effect is not entirely eliminated by the Fe correction; therefore, caution should be used when applying these data.

\section{Site 849}

The primary objective of Site 849 was to record the history of the late Neogene equatorial divergence in the eastern equatorial Pacific in an area dissociated from the direct effects of the eastern boundary of the Pacific. This site is located in a present-day divergence zone drilled along the western north-south transect of Leg 138. Gaining an understanding of the regional and global response of the equatorial Pacific to climate change was another objective of a series of studies in which this transect is the eastern end-member (Shipboard Scientific Party, 1992f). Site 849 encountered sediment described in one lithologic unit. The portion of the logging data recorded through pipe, 


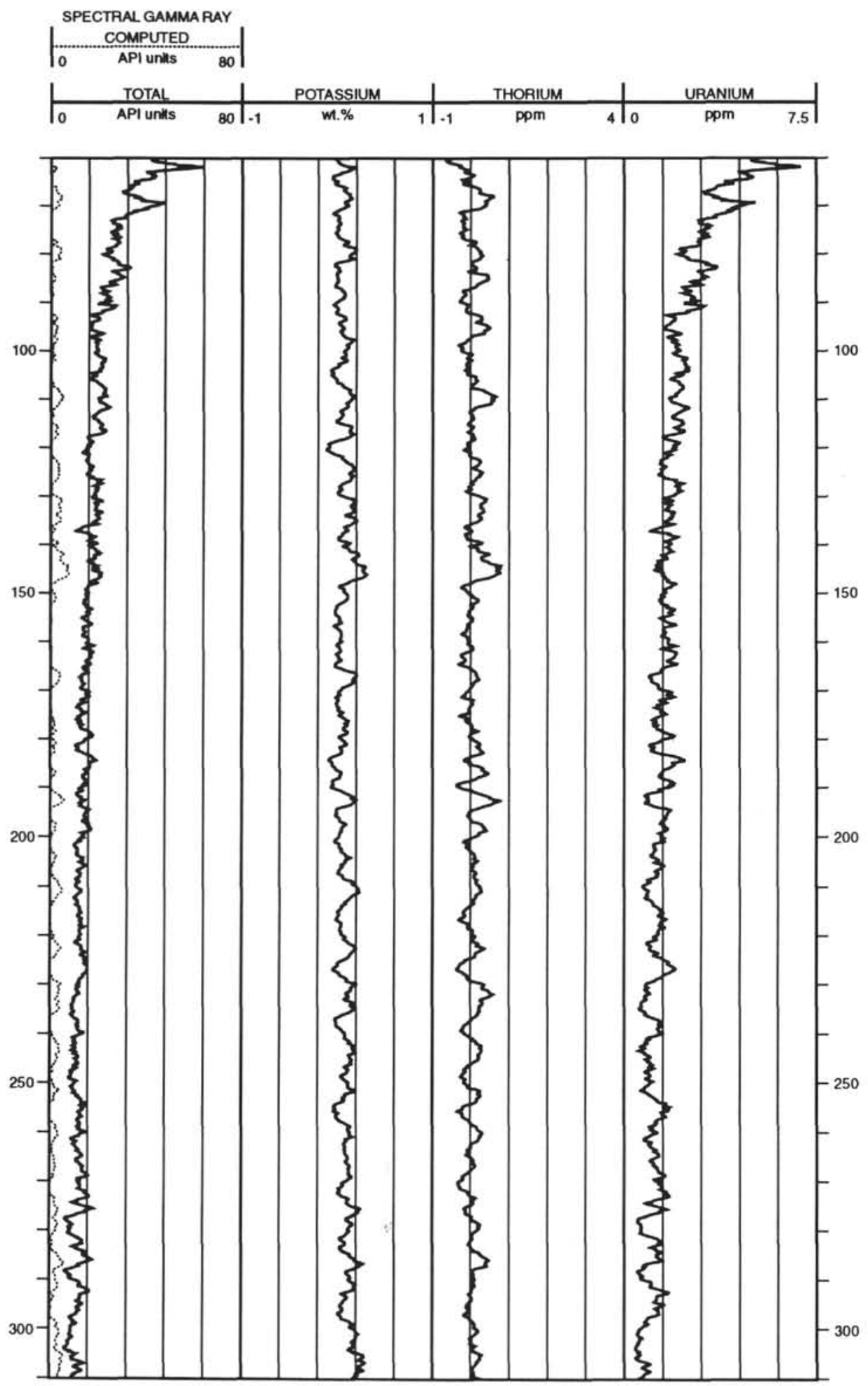

Figure 7. Processed natural gamma-ray data, Hole 846B.

above $50.6 \mathrm{mbsf}$, was not processed because of the low percentage of readings; hence, any lithologic interpretation of log character change would be questionable. The only lithologic unit ( $0-350.5 \mathrm{mbsf})$, from Pleistocene to late Miocene in age, is dominantly diatom nannofossil ooze with minor intervals of diatom ooze, as seen in the logs by a high $\mathrm{CaCO}_{3}$ value (Shipboard Scientific Party, 1992f).
The processed natural gamma-ray curves from Hole 849B, shown in Figure 13, are from the geochemical logging tool string. Figure 14 displays the oxide-weight fractions estimated from the logs at Hole $849 \mathrm{~B}$, along with calculated statistical uncertainties of each element. An additional five-point smoothing was need for the elemental yields and a 10-point smoothing was necessary for the Fact curve to remove 

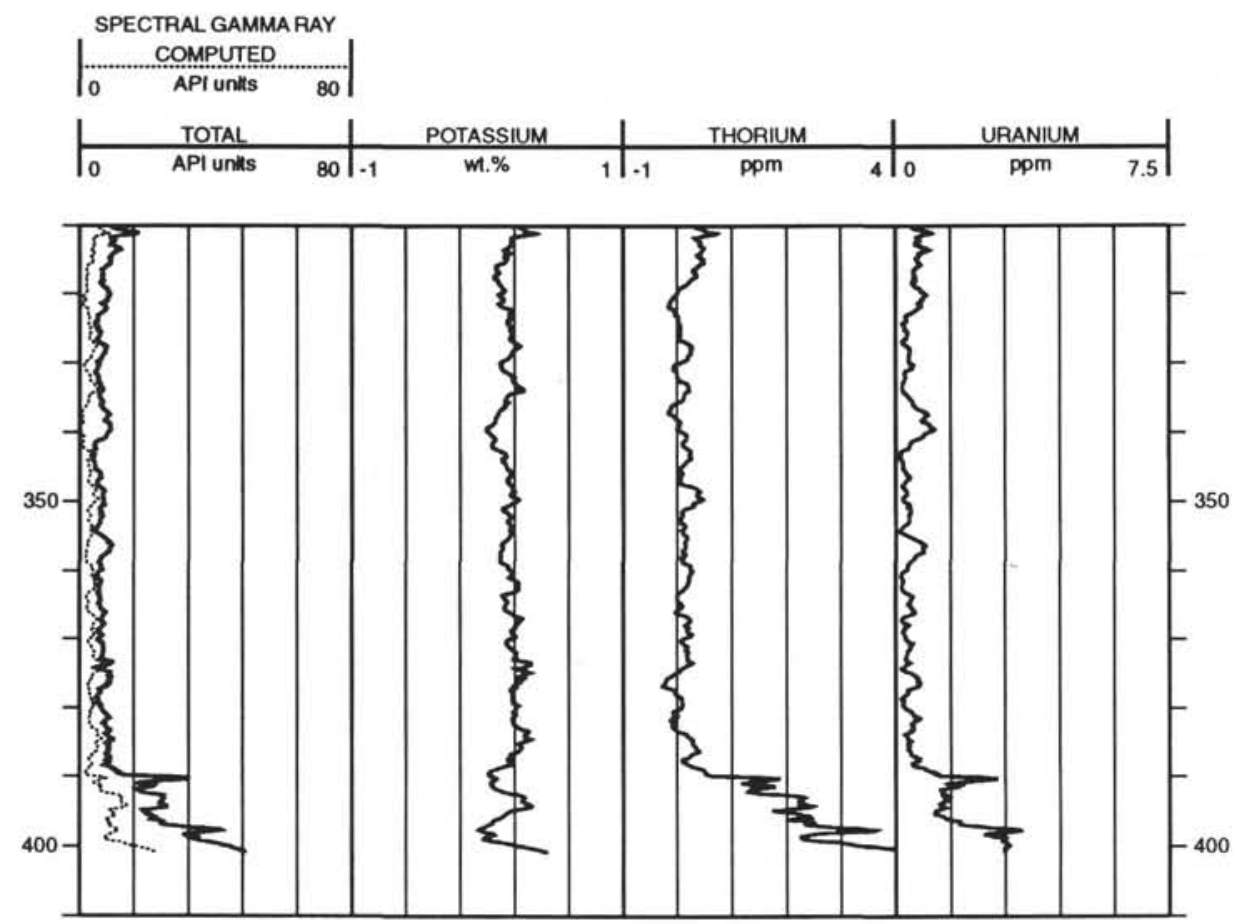

Figure 7 (continued).

noise in the data. A discrimination program was also applied to the Fact curve to eliminate all values higher than 1200 , which were inducing erroneous noise in the final data. The $\mathrm{Al}, \mathrm{K}$, and SGR curves were extrapolated to process the bottom $10 \mathrm{~m}$ of the GLT data. The GLT data are poor from this hole because of the extremely high porosity values, thus causing the tool readings to be dominated by the fluid readings, rather than by the formation. This is indicated by the high Fact values. To explain the high Fact readings, we included two additional columns in Figure 14. The column adjacent to the variable Ca-oxide factor curve is the summation curve. This summation curve represents the percentage of the readings of the tool from the rock. As seen in the log, the tool reads nearly $100 \%$ from the rock in most of the hole and yet reads barely $20 \%$ from the rock in isolated zones. The far-right column displays the porosity curve used in these calculations, mainly to show the extremely high porosity values that dominate this hole. Available core measurements of $\mathrm{CaCO}_{3}$ and XRF major elemental analyses are displayed as solid diamonds and solid circles, respectively, for comparison with the oxide weight fractions derived from the logging data. Site 849 core measurements were taken from three holes. Cores from Holes $849 \mathrm{~B}$ and $849 \mathrm{C}$ contributed to the physical-properties data. Holes $849 \mathrm{~B}$ and $849 \mathrm{D}$ cores contributed to the XRF data, and Hole $849 \mathrm{~B}$ contributed to the $\mathrm{CaCO}_{3}$ data.

The $\mathrm{CaCO}_{3}$ log-core agreement is good throughout the sediment section. The XRF core-to-log comparison is good; however, only four XRF samples were analyzed in two selected intervals of the hole, which may indicate a bias in the sampling, as the samples are too close to be distinguished in the logs.

\section{Site $\mathbf{8 5 0}$}

The primary objective of Site 850 was to provide a high spatial resolution of the steep Pacific equatorial divergence gradient. This site lies midway between Sites 849 and 851 , approximately $9 \mathrm{~km}$ north of a seamount, the sediment sequence at Site 850 appears to be unaffected beyond this feature (Shipboard Scientific Party, 1992g). In Site 850, sediments were encountered that were described as one lithologic unit. The portion of the logging data recorded through pipe, above 47.2 mbsf, was not processed because of the low percentage of readings; hence, any lithologic interpretation of log character change would be questionable. The middle Miocene to Pleistocene unit is a continuous sediment accumulation dominated by nannofossil ooze with minor amounts of diatom ooze (Shipboard Scientific Party, 1992g).

The processed natural gamma-ray curves from Hole $850 \mathrm{~B}$, shown in Figure 15, are from the GLT tool string. A large spike from 254.0 to $258.5 \mathrm{mbsf}$, caused when the tool briefly fell out of calibration, was eliminated by interpolation of all raw elemental-yield and ACT data. Figure 16 displays the oxide-weight fractions estimated from the logs at Hole $850 \mathrm{~B}$, along with calculated statistical uncertainties of each element. The normalization factor is displayed to the right of the logs, along with a $\log$ of the Ca-oxide factor. An additional five-point smoothing was necessary for the elemental yields to remove noise from the data. Available core measurements of $\mathrm{CaCO}_{3}$ and XRF major elemental analyses are displayed as solid diamonds and solid circles, respectively, for comparison with the oxide-weight fractions derived from the logging data. Site 850 core measurements were taken from two holes. Cores from Hole $850 \mathrm{~A}$ contributed to the physicalproperties data. Holes $850 \mathrm{~A}$ and $850 \mathrm{~B}$ contributed to the $\mathrm{CaCO}_{3}$ and XRF core measurements.

The $\mathrm{CaCO}_{3}$ and XRF core-log agreement is good throughout the sediment section. The XRF core measurements were taken from the first section of most cores to provide an average record of the sediment chemistry, and show very good agreement with the logs.

\section{Site 851}

The primary objective of Site 851 was to obtain a historical record of the South Equatorial Current and to document the boundary movement between the North Equatorial Countercurrent and the South Equatorial Current. This site is on the crust formed at the East Pacific Rise, near the southern limit of the seasonal migration of the boundary between the North Equatorial Current and the South Equatorial Countercurrent (Shipboard Scientific Party, 1992h). One lithologic unit was encountered at Site 851 , which was described as Pleistocene to middle Miocene in age. The portion of the logging data recorded through pipe, above $62 \mathrm{mbsf}$, was not processed because of the low percentage of readings; hence, any lithologic interpretation 

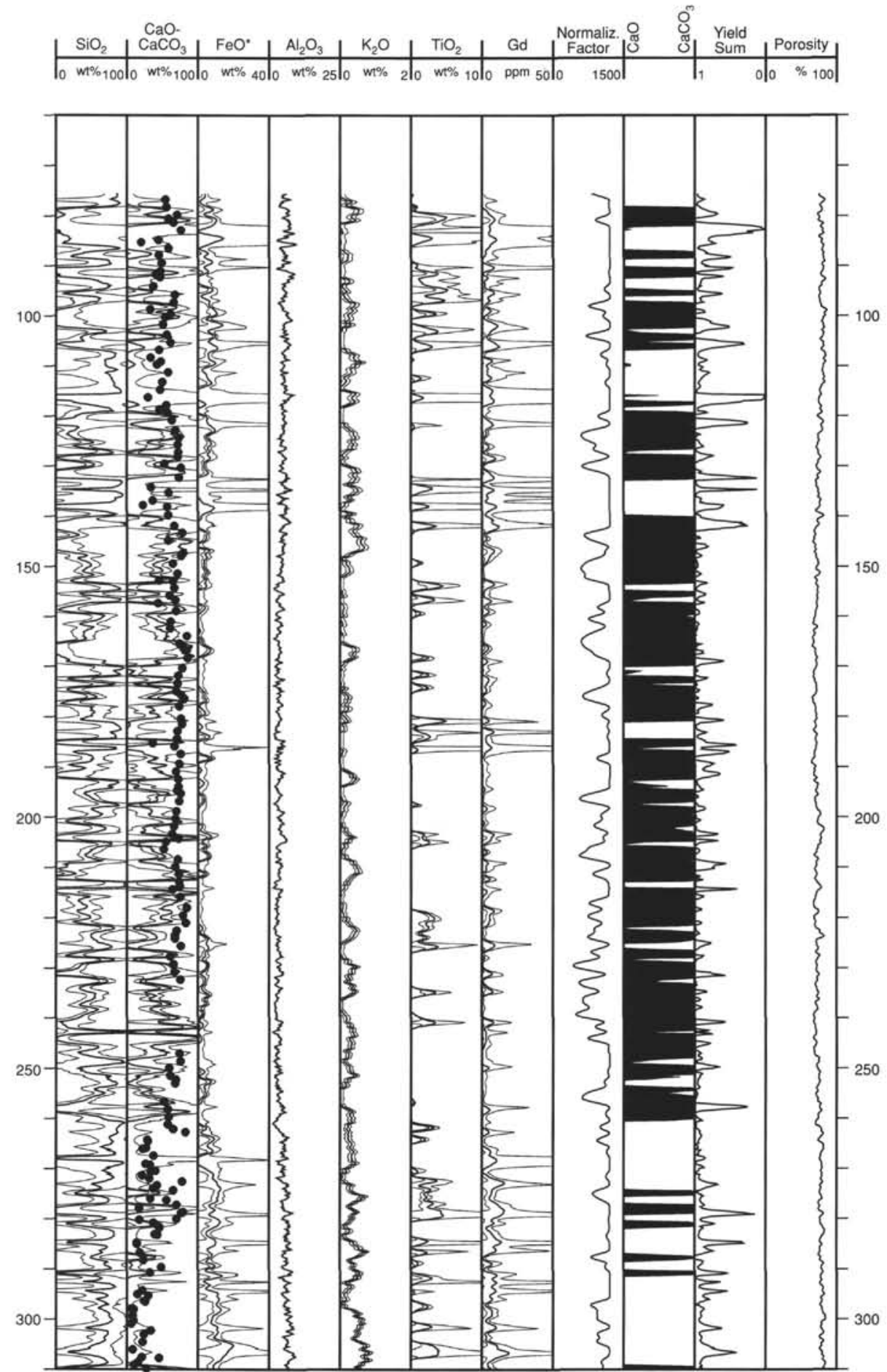

Figure 8. Estimates of calcium carbonate and major oxide-weight fractions from geochemical logs, Hole 846B. Solid diamonds represent $\mathrm{CaCO}_{3}$ measurements (Shipboard Scientific Party, 1992c). The additional curves included are yield sum that displays the sum of the yields attributed to the rock, and porosity that displays is associated high-porosity percentages in this rock.

of log-character change would be questionable. Four subunits are defined from the different characteristics of the sediment sequence. The first subunit (0-76.5 mbsf) contains a high percentage of $\mathrm{CaCO}_{3}$ and is described as Pleistocene and lower Pliocene foraminifer nannofossil ooze. Early Pliocene and Miocene is the age of the second subunit (76.5-205.0 mbsf), described as diatom nannofossil ooze with a high percentage of $\mathrm{CaCO}_{3}$. The third subunit (205.0-287.0 mbsf) consists of upper to middle Miocene diatom ooze interbedded with diatom nannofossil ooze. And the last subunit (287.0-basement) is described as middle Miocene nannofossil ooze and chalk with diatoms and radiolarians (Shipboard Scientific Party, 1992h). The last subunit is distinguished on the logs by a lower $\mathrm{CaO} / \mathrm{CaCO}_{3}$ value. The pro- 

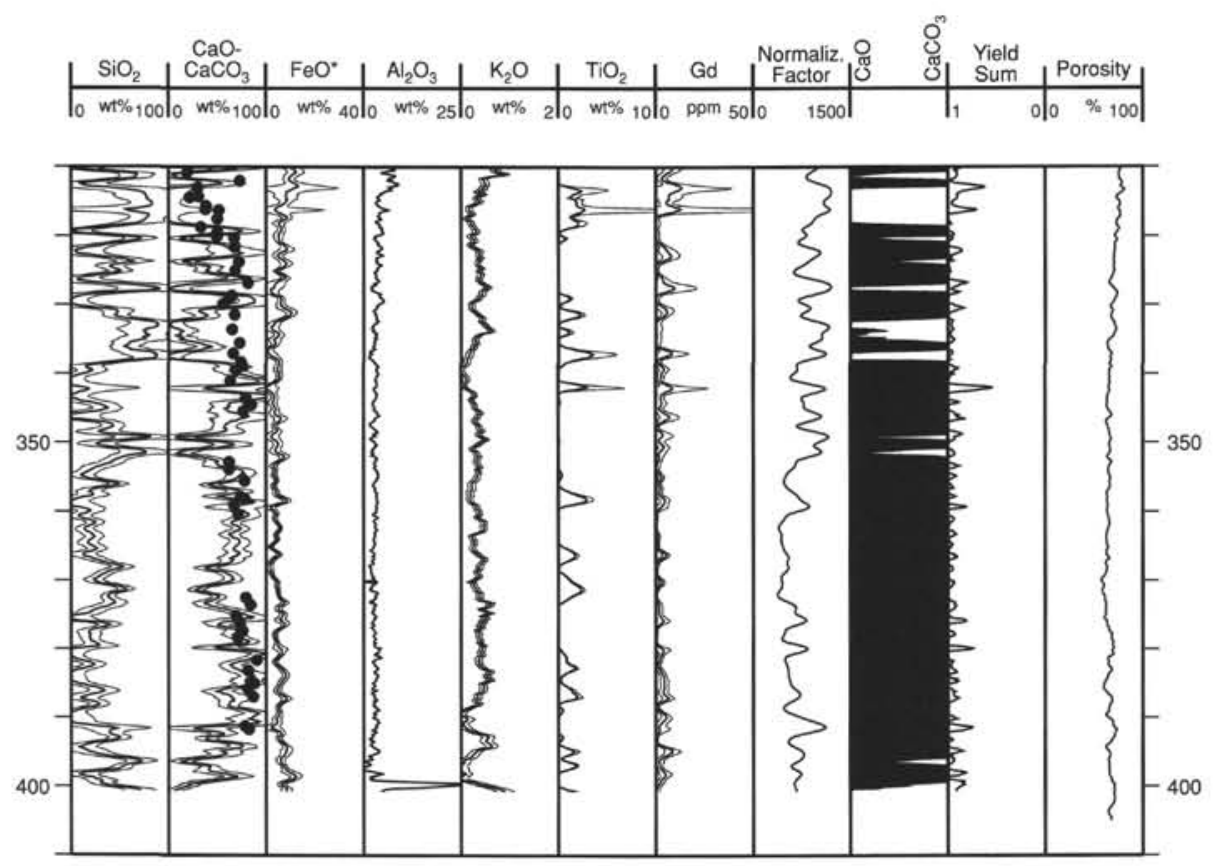

Figure 8 (continued).

cessed natural gamma-ray curves at Hole 851B, shown in Figure 17, are from the GLT tool string. Figure 18 displays the oxide-weight fractions estimated from the logs at Hole $851 \mathrm{~B}$, along with calculated statistical uncertainties of each element (Grau et al., 1990; Schweitzer et al., 1988). The normalization factor is displayed to the right of the logs along with a log of the Ca-oxide factor. An additional five-point smoothing was necessary for the elemental yields to remove noise from the data. Both the $\mathrm{Al}$ and $\mathrm{K}$ curves were extrapolated to process the top $10 \mathrm{~m}$ and bottom $15 \mathrm{~m}$ of the GLT data. Available core measurements of $\mathrm{CaCO}_{3}$ and XRF major elemental analyses are displayed as solid diamonds and solid circles, respectively, for comparison with the oxide weight fractions derived from the logging data. Site 851 core measurements were taken from two holes. Cores from Holes $851 \mathrm{~B}$ and $851 \mathrm{E}$ contributed to the physical properties data and the XRF data. Hole $851 \mathrm{~B}$ contributed to the $\mathrm{CaCO}_{3}$ data.

The $\mathrm{CaCO}_{3}$ log-core agreement is good throughout most of the sediment section. The XRF core measurements were taken from the first section of most cores to provide an average record of the sediment chemistry and agree well with the logs.

\section{Site 852}

The primary objective of Site 852 was to obtain a historical record of the North Equatorial Countercurrent and the South Equatorial Current and their relationship to climatic forcing during the late Neogene. This site is on the crust that formed at the East Pacific Rise in the eastward flowing North Equatorial Current near the northern seasonal boundary between the South Equatorial Current and the North Equatorial Countercurrent (Shipboard Scientific Party, 1992i). In Site 852, sediments were encountered that were described as one lithologic unit. These Pliocene and Pleistocene sediments are a mixture of foraminifer nannofossil ooze and nannofossil foraminifer ooze with common oxide-rich beds, indicated in the logs by the $\mathrm{FeO}^{*}$ spikes in the openhole interval. Miocene and lower Pliocene radiolarian nannofossil ooze underlies the Pliocene and Pleistocene sediments (Shipboard Scientific Party, 1992i).

The processed natural gamma-ray curves at Hole 852D, shown in Figure 19 are from the GLT string, which was the only logging tool run in Hole 852D. During calibration, noise spikes appeared in the raw records from the bottom of the hole. The following depths indicate the start of the good data: gamma ray/U-Th-K $(0-101.3$ mbsf), Al (0-107.6 mbsf), and GLT (0-115.4 mbsf); the bottom depths vary from tool to tool because of the different position of each tool on the tool string (Fig. 2). The hole was activated near the pipe entry because of the slight delay of the tool in attempts to make it enter the pipe. Because of this activation at the pipe entry, large spikes appear in the $\mathrm{Al} \log$ reading in the interval between 39 and $45 \mathrm{mbsf}$; therefore, interpolation was used to eliminate the spikes in the processed logging data. Figure 20 displays the oxide-weight fractions estimated from the logs from Hole 852D, along with calculated statistical uncertainties of each element. This normalization factor is displayed to the right of the logs along with a log of the Ca-oxide factor. Almost one-half the data was recorded through pipe; the pipe depth is approximately $49 \mathrm{mbsf}$. The Fe curve was used to calibrate the through-pipe section with the openhole section in an attempt to eliminate the pipe effect in the readings. The logging data recorded through pipe produced a low percentage of readings from the rock; hence, any lithologic interpretation of log-character change would be questionable. In addition to the pipe-entry correction of the data, the elemental aluminum curve also had spikes in the interval from 25 to $39 \mathrm{mbsf}$ that were eliminated by interpolation. Available core measurements of $\mathrm{CaCO}_{3}$ and XRF major elemental analyses are displayed as solid diamonds and solid circles, respectively, for comparison with the oxide-weight fractions derived from the logging data. Site 852 core measurements were taken from two holes. Cores from Holes $852 \mathrm{~B}$ and $852 \mathrm{C}$ contributed to the physical properties data. Hole $852 \mathrm{~B}$ cores contributed to the XRF and $\mathrm{CaCO}_{3}$ data.

The $\mathrm{CaCO}_{3}$ core-log correlation is good in open hole and is poor in the cased-hole section of the log. The pipe effect was not entirely eliminated by the Fe correction; therefore, caution should be used when applying these data. The XRF core-log correlation is good in the open-hole section and relatively good in the cased-hole section, except for the $\mathrm{SiO}_{2}$ curve.

\section{SUMMARY}

The GLT measurements provide continuous, in-situ chemical measurements of the sedimentary section. Improvement in natural gamma-ray $\log$ measurements can be obtained by data reprocessing, which incorporates better calibrations of Th, $\mathrm{U}$, and $\mathrm{K}$ and hole-size 


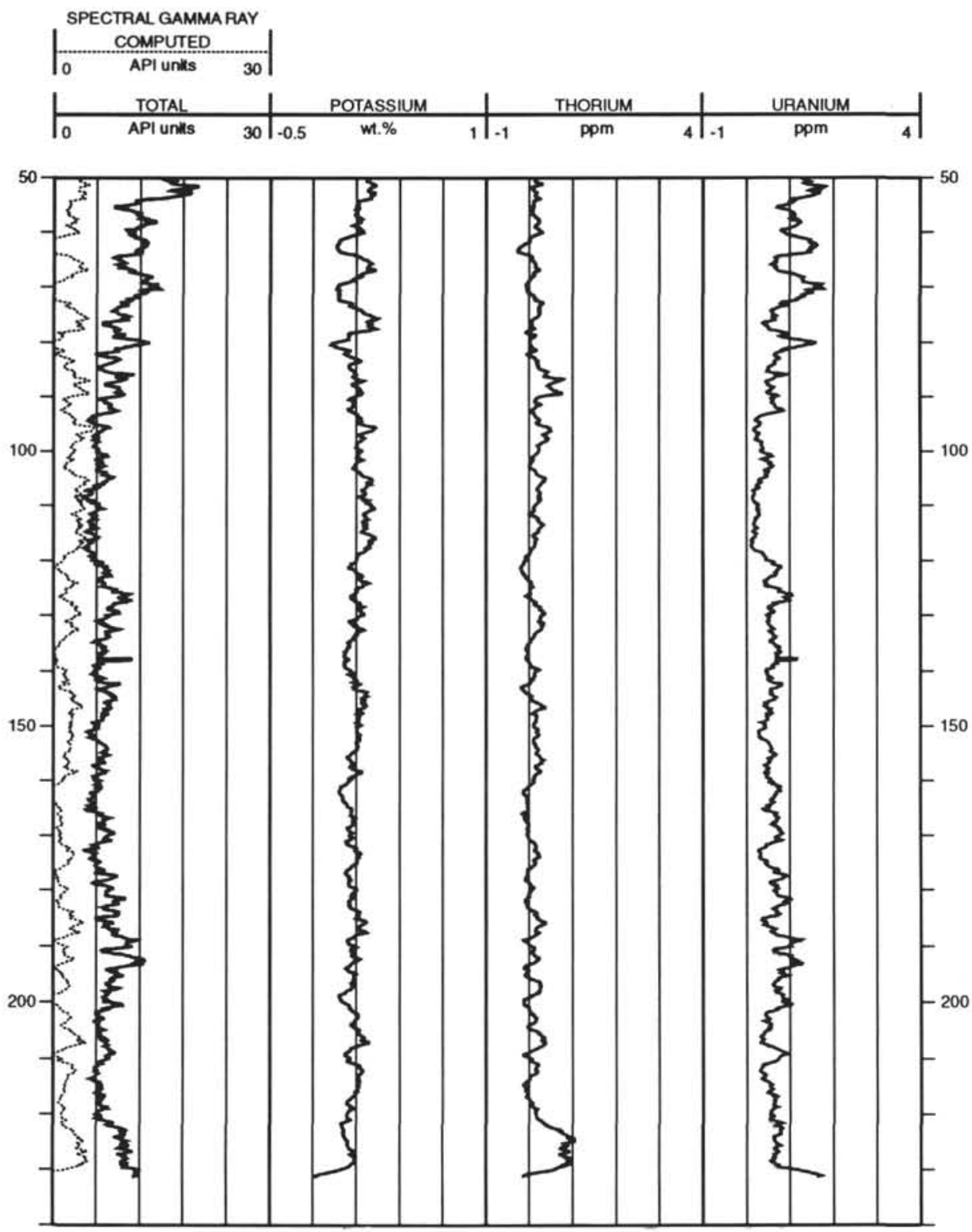

Figure 9. Processed natural gamma-ray data, Hole 847B.

corrections. The information from the GLT, through reprocessing, was converted into elemental and oxide measurements, which can be compared to core measurements. Unlike missing or sparse core data, the reprocessed logging data provide an invaluable continuous data set from which one may interpret lithology.

A new neutron-derived porosity-calculation method was used during this leg with the CNT from the GLT log (Truax, 1992). After comparing the results of the porosity calculations of both the density and neutron-derived methods, we found that the neutron-derived porosity method was the best porosity-calculation method for use in these high-porosity sediments.

During Leg 138, 11 sites were drilled on three lithospheric plates of the eastern Pacific: the Cocos, Nazca, and Pacific, for obtaining data about the response of global climate changes during Neogene time. The geochemical processing was performed only in openhole sections of Holes 844B, 845B, 846B, 847B, 849B, 850B, and 851B. Both through-pipe and openhole sections were processed in Holes $848 \mathrm{~B}$ and $852 \mathrm{D}$. The $\mathrm{CaCO}_{3}$ core-log agreement is good throughout the sediment sections of Holes 844B, 845B, 846B, 847B, 849B, 850B, 851B, and the openhole section of $852 \mathrm{D}$. The comparison of XRF core data to logging data is good in Holes $850 \mathrm{~B}, 851 \mathrm{~B}$, and the openhole section of $852 \mathrm{D}$; and relatively good but with limited core sampling in Holes $844 \mathrm{~B}, 845 \mathrm{~B}$, and $849 \mathrm{~B}$. Holes $846 \mathrm{~B}$ and $847 \mathrm{~B}$ had no XRF core data in the logged intervals for comparison. Both the $\mathrm{CaCO}_{3}$ and the XRF core data compare poorly with the logged data in Hole $848 \mathrm{~B}$, which was logged, almost entirely, through pipe. The sections logged through pipe of Hole $852 \mathrm{D}$ compare poorly with $\mathrm{CaCO}_{3}$ core data; however, the comparison to XRF core data is relatively good, except for $\mathrm{SiO}_{2}$. Leg 138 hole results are displayed in Table 2.

\section{REFERENCES ${ }^{*}$}

Grau, J.A., and Schweitzer, J.S., 1989. Elemental concentrations from thermal neutron capture gamma-ray spectra in geological formations. Nucl. Geophys., 3:1-9.

\footnotetext{
- Abbreviations for names of organizations and publication titles in ODP reference lists follow the style given in Chemical Abstracts Service Source Index (published by American Chemical Society).
} 
Grau, J.A., Schweitzer, J.S., and Hertzog, R.C., 1990. Statistical uncertainties of elemental concentrations extracted from neutron induced gamma-ray measurements. IEEE Trans. Nucl. Sci., 37:2175-2178.

Hertzog, R., Colson, L., Seeman, B., O’Brien, M., Scott, H., McKeon, D., Wraight, J., Grau, J., Ellis, D., Schweitzer, J., and Herron, M., 1989. Geochemical logging with spectrometry tools. SPE Form. Eval., 4:153-162.

Lock, G.A., and Hoyer, W.A., 1971. Natural gamma-ray spectral logging. Log Analyst, 12:3-9.

Mayer, L., Pisias, N., Janecek, T., et al., 1992. Proc. ODP, Init. Repts., 138 (Pts. 1 and 2): College Station, TX (Ocean Drilling Program).

Pratson, E.L., Broglia, C., and Jarrard, R., 1993. Data report: geochemical well logs through Cenozoic and Quaternary sediments from Sites 815, 817, 820, 822, and 823. In McKenzie, J.A., Davies, P.J., Palmer-Julson, A., et al., Proc. ODP, Sci. Results, 133: College Station, TX (Ocean Drilling Program), 795-817.

Ruckebusch, G., 1983. A Kalman filtering approach to natural gamma ray spectroscopy in well logging. IEEE Trans. Autom. Control, AC-28:372-380.

Schweitzer, J.S., Grau, J.A., and Hertzog, R.C., 1988. Precision and accuracy of short-lived activation measurements for in situ geological analyses. $J$. Trace Microprobe Techniques, 6:437-451.

Shipboard Scientific Party, 1992a. Site 844. In Mayer, L., Pisias, N., Janecek, T., et al., Proc. ODP, Init. Repts., 138 (Pt. 1): College Station, TX (Ocean Drilling Program), 119-188.

1992b. Site 845. In Mayer, L., Pisias, N., Janecek, T., et al., Proc. ODP, Init. Repts., 138 (Pt. 1): College Station, TX (Ocean Drilling Program), 189-263.

, 1992c. Site 846. In Mayer, L., Pisias, N., Janecek, T., et al., Proc. ODP, Init. Repts., 138 (Pt. 1): College Station, TX (Ocean Drilling Program), 265-333. 1992d. Site 847. In Mayer, L., Pisias, N., Janecek, T., et al., Proc. ODP, Init. Repts., 138 (Pt. 1): College Station, TX (Ocean Drilling Program), 335-393.

1992e. Site 848. In Mayer, L., Pisias, N., Janecek, T., et al., Proc. $O D P$, Init. Repts., 138 (Pt. 2): College Station, TX (Ocean Drilling Program), 677-734.

, 1992f. Site 849. In Mayer, L., Pisias, N., Janecek, T., et al., Proc. ODP, Init. Repts., 138 (Pt. 2): College Station, TX (Ocean Drilling Program), 735-807.

1992g. Site 850. In Mayer, L., Pisias, N., Janecek, T., et al., Proc. ODP, Init. Repts., 138 (Pt. 2): College Station, TX (Ocean Drilling Program), 809-889.

, 1992h. Site 851. In Mayer, L., Pisias, N., Janecek, T., et al., Proc. ODP, Init. Repts., 138 (Pt. 2): College Station, TX (Ocean Drilling Program), 891-965.

, 1992i. Site 852. In Mayer, L., Pisias, N., Janecek, T., et al., Proc. ODP, Init. Repts., 138 (Pt. 2): College Station, TX (Ocean Drilling Program), 967-1021.

Truax, J., 1992. Wireline Neutron Log Response in High Porosity Sediments Encountered on the Ocean Drilling Project: Ridgefield, CT (Schlumberger-Doll Research).

Date of initial receipt: 28 January 1993

Date of acceptance: 28 December 1993

Ms 138SR-154 
Table 2. Results of core vs. log comparison for Leg 138 holes.

\begin{tabular}{|c|c|c|c|c|c|c|c|c|c|c|}
\hline \multirow[b]{2}{*}{ Site } & \multicolumn{2}{|c|}{$\begin{array}{l}\text { Geochemical } \\
\text { processing }\end{array}$} & \multicolumn{4}{|c|}{$\begin{array}{c}\mathrm{CaCO}_{3} \\
\text { log-core agreement }\end{array}$} & \multicolumn{4}{|c|}{$\begin{array}{c}\text { XRF } \\
\text { log-core agreement }\end{array}$} \\
\hline & $\begin{array}{l}\text { Open } \\
\text { hole }\end{array}$ & $\begin{array}{l}\text { Thru } \\
\text { pipe }\end{array}$ & Good & Fair & Poor & $\begin{array}{l}\text { No } \\
\text { data }\end{array}$ & Good & Fair & Poor & $\begin{array}{l}\text { No } \\
\text { data }\end{array}$ \\
\hline 844 & $X$ & & $X$ & & & & & $X$ & & \\
\hline 845 & $X$ & & $x$ & & & & & $x$ & & \\
\hline 846 & $X$ & & $X$ & & & & & & & $x$ \\
\hline 847 & $x$ & & $X$ & & & & & & & $X$ \\
\hline 848 & $X$ & $X$ & & & & & & & $X$ & \\
\hline 849 & $X$ & & $X$ & & & & & $\mathrm{X}$ & & \\
\hline 850 & $x$ & & $\mathrm{X}$ & & & & $X$ & & & \\
\hline 851 & $X$ & & $X$ & & & & $\mathrm{X}$ & & & \\
\hline 852 & $x$ & $X$ & & $x$ & & & & $\mathrm{X}$ & & \\
\hline
\end{tabular}

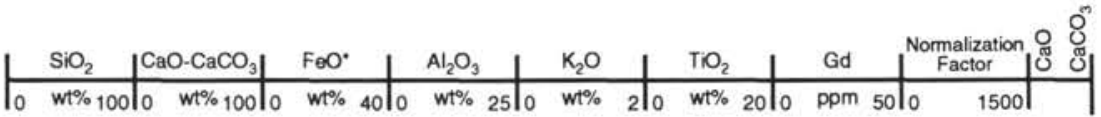

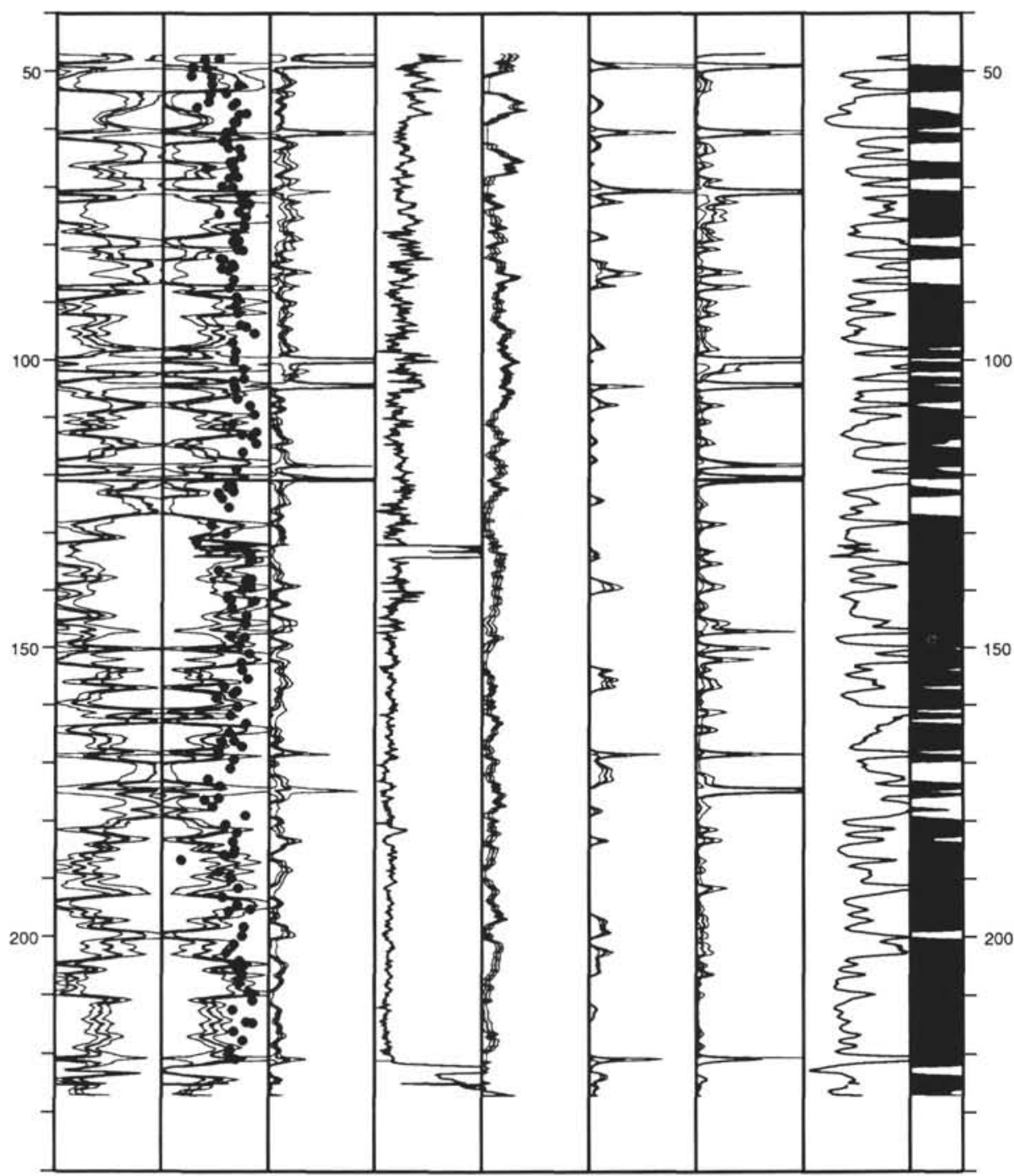

Figure 10. Estimates of calcium carbonate and major oxide-weight fractions from geochemical logs, Hole 847B. Solid diamonds represent $\mathrm{CaCO}_{3}$ measurements (Shipboard Scientific Party, 1992d). 

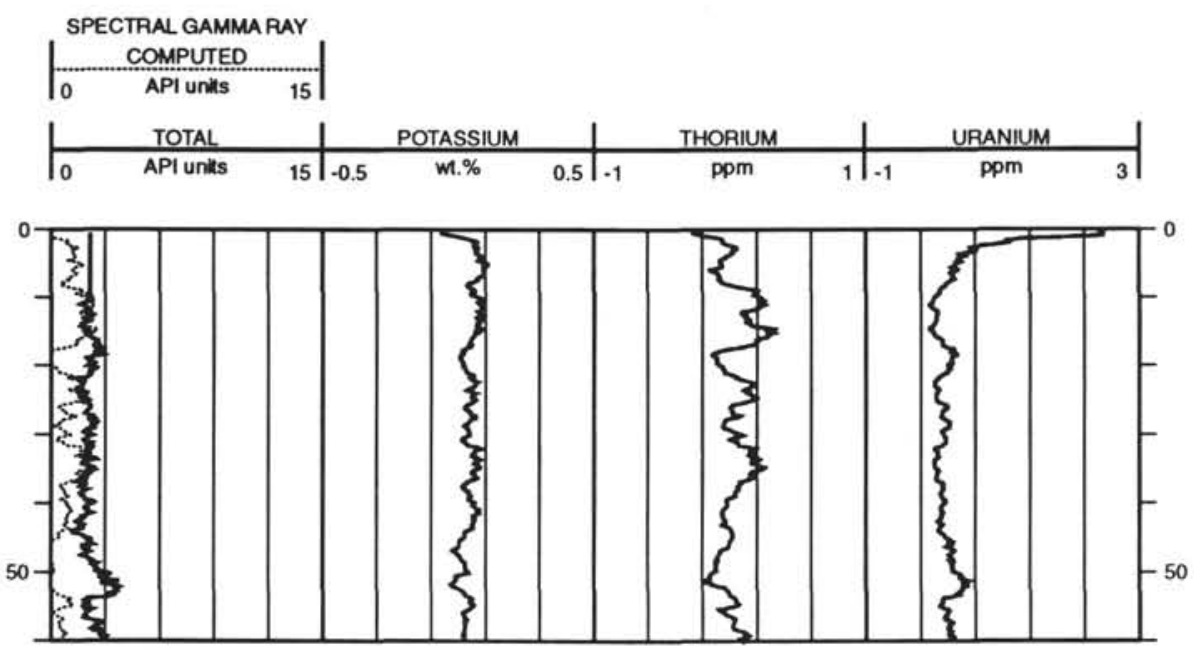

Figure 11. Processed natural gamma-ray data, Hole 848B.
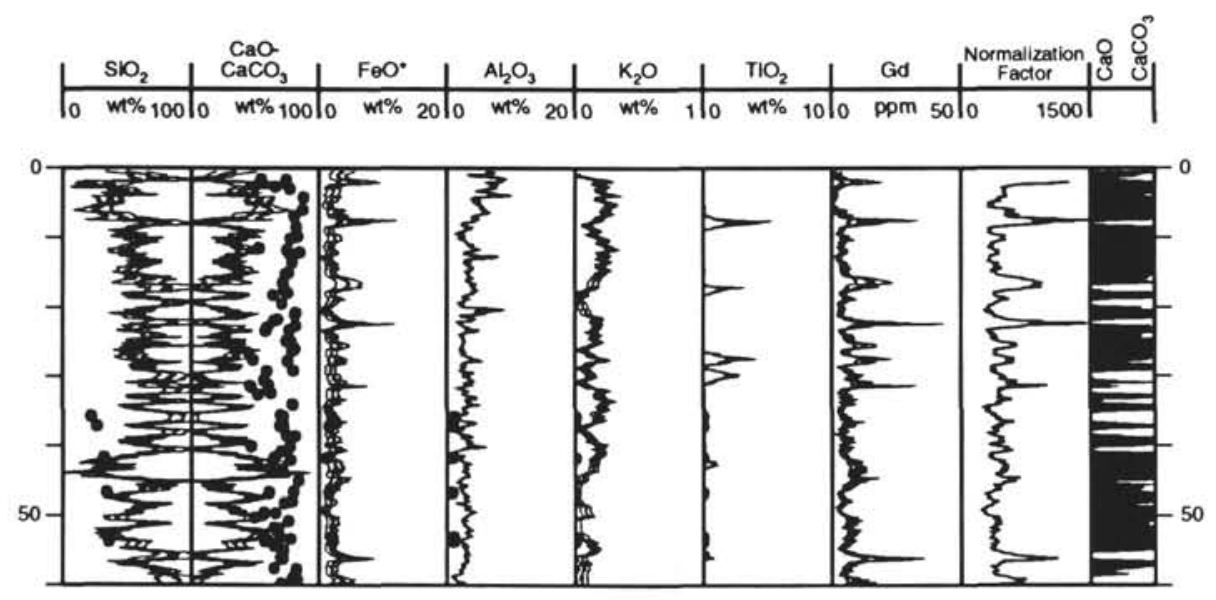

Figure 12. Estimates of calcium carbonate and major oxide-weight fractions from geochemical logs, Hole 848B. Solid diamonds and solid circles represent $\mathrm{CaCO}_{3}$ and XRF measurements, respectively (Shipboard Scientific Party, 1992e). 


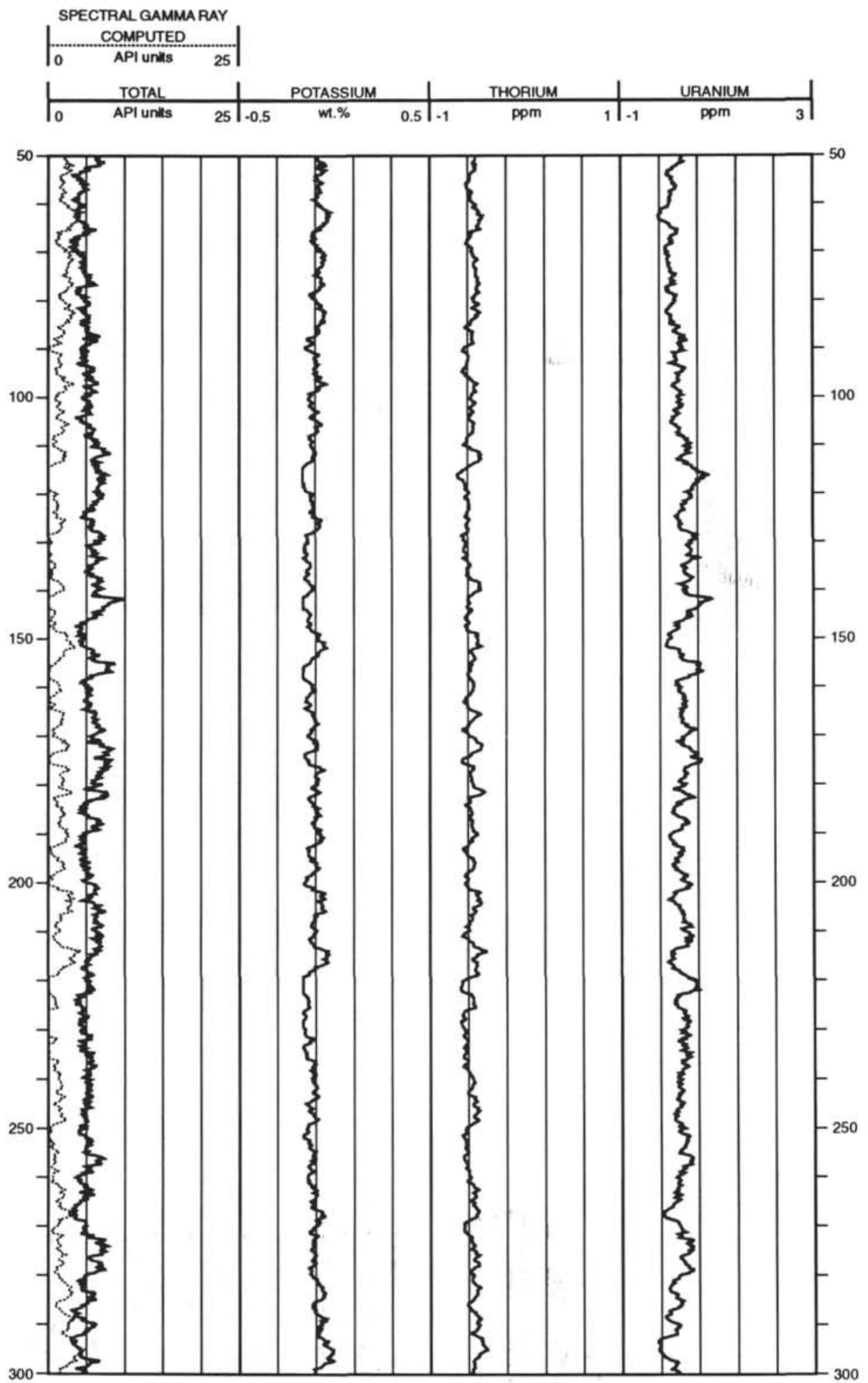

Figure 13. Processed natural gamma-ray data, Hole 849B. 


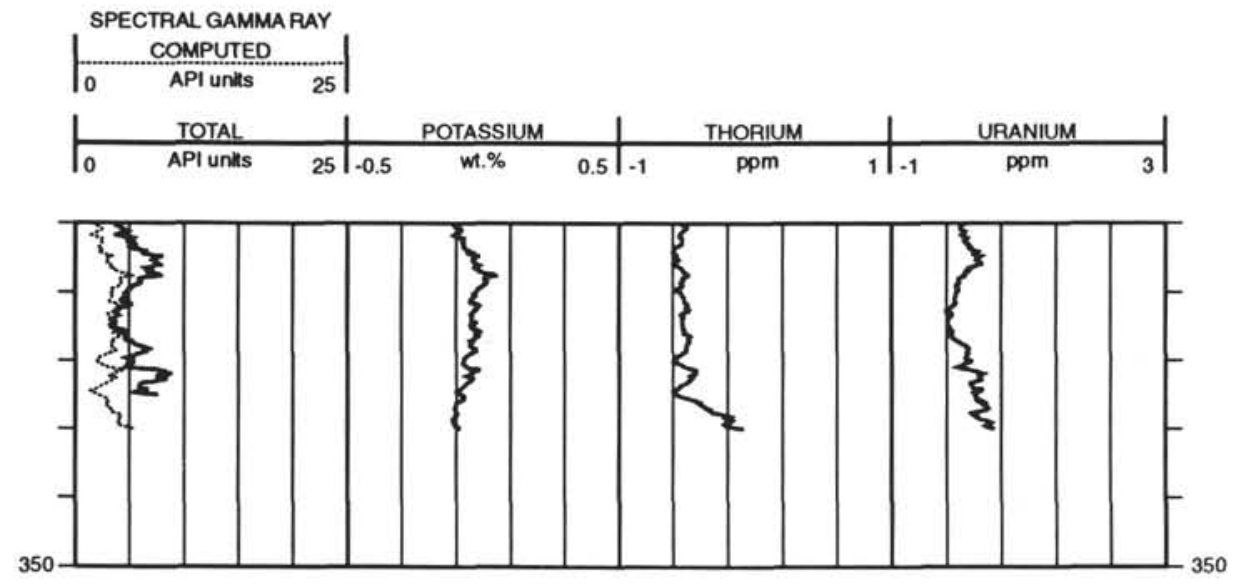

Figure 13 (continued). 


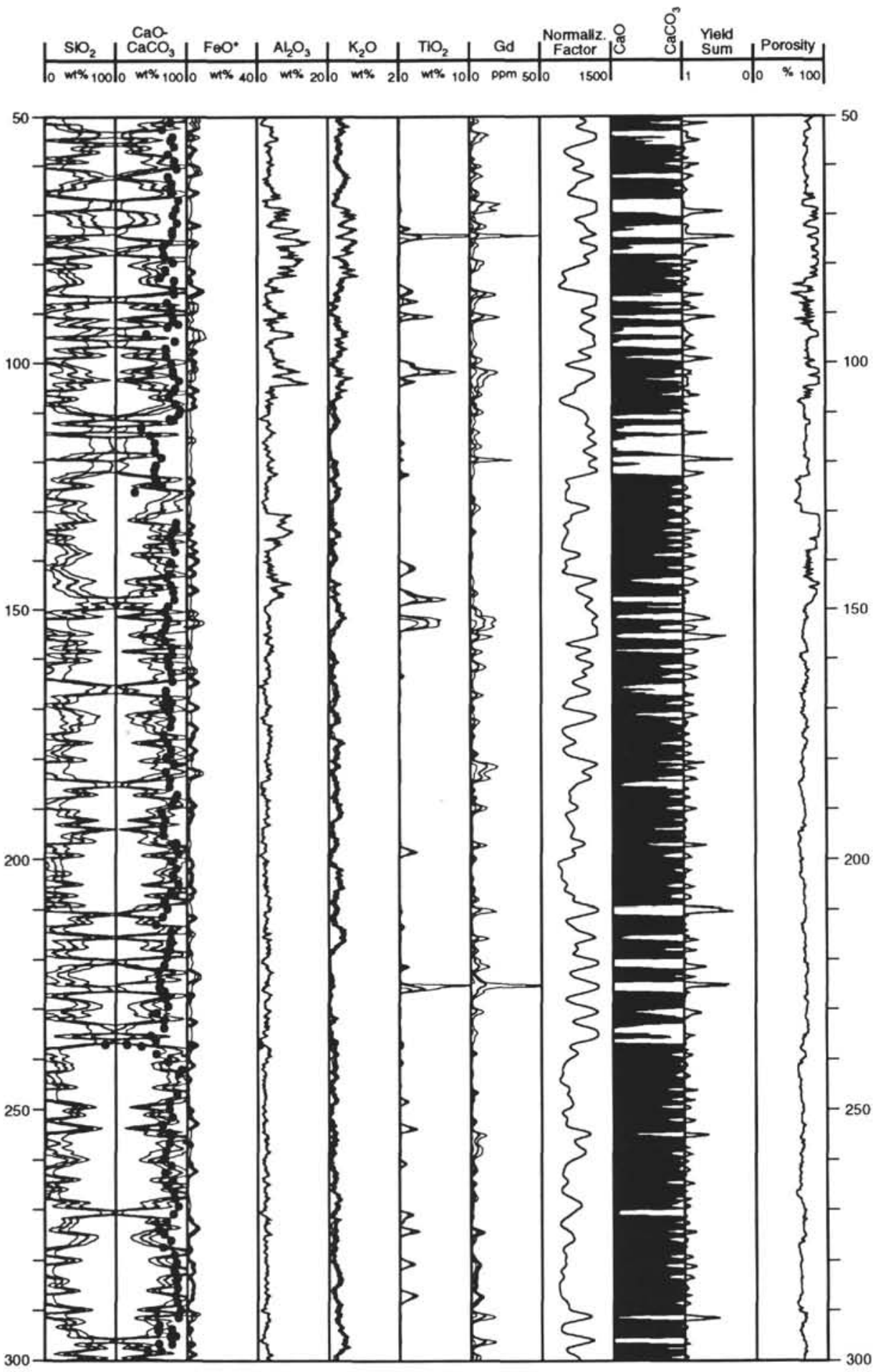

Figure 14. Estimates of calcium carbonate and major oxide-weight fractions from geochemical logs, Hole 849B. Solid diamonds and solid circles represent $\mathrm{CaCO}_{3}$ and XRF measurements, respectively (Shipboard Scientific Party, 1992f). The additional curves included are yield sums that display the sum of the yields attributed to the rock, and porosity displays the associated high-porosity percentages in this rock. 


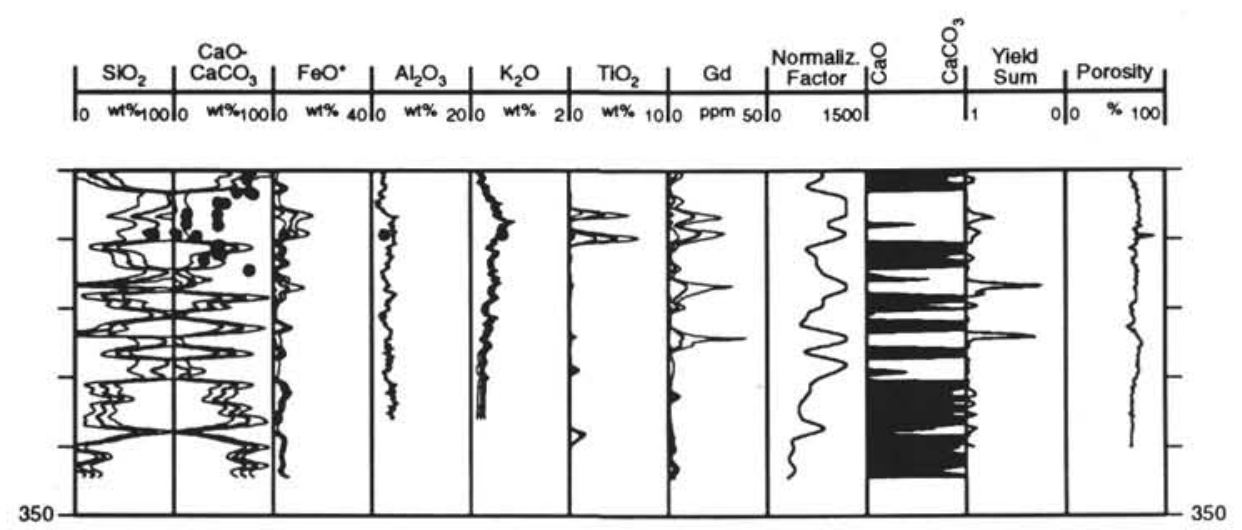

Figure 14 (continued). 

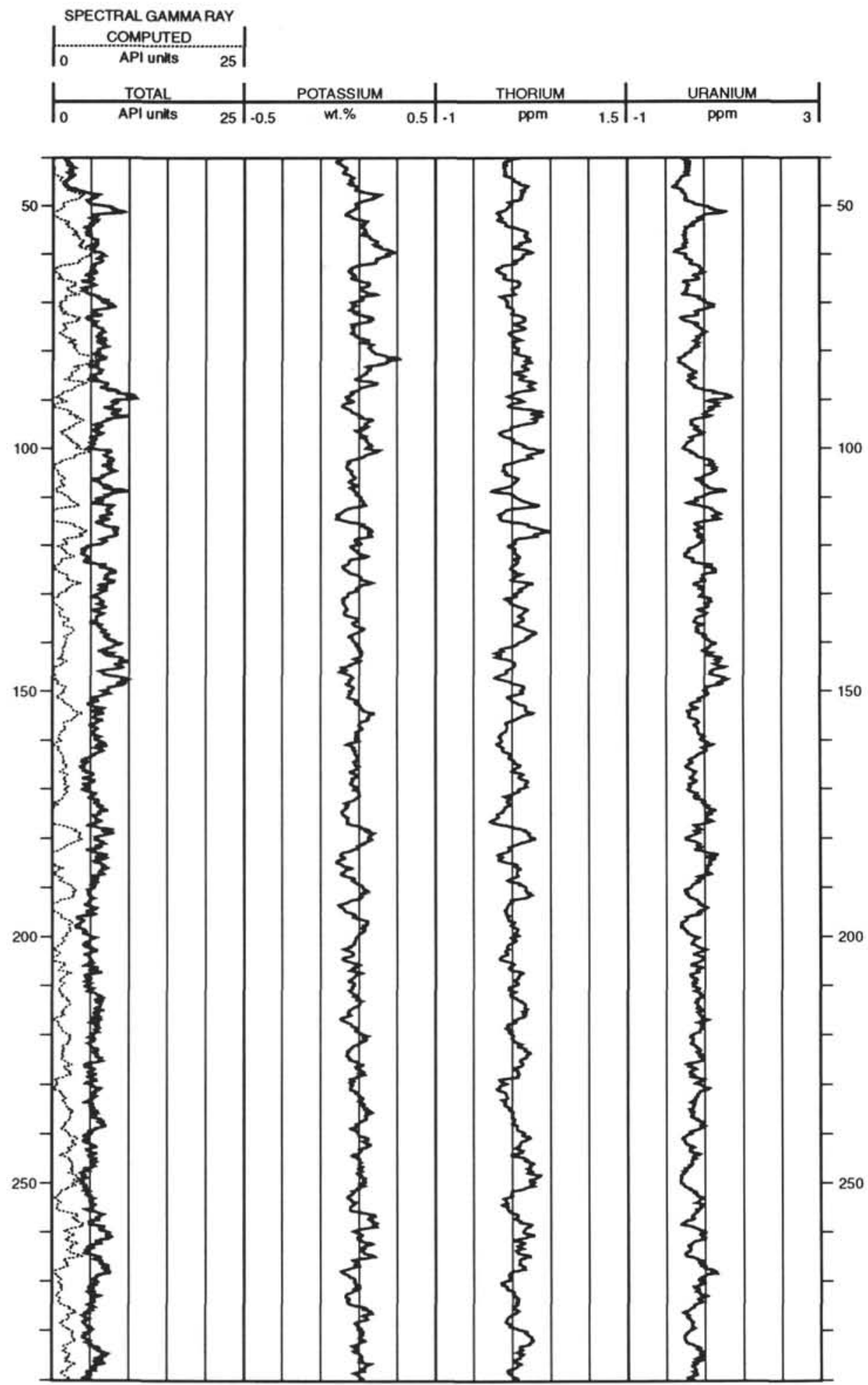

Figure 15. Processed natural gamma-ray data, Hole 850B. 


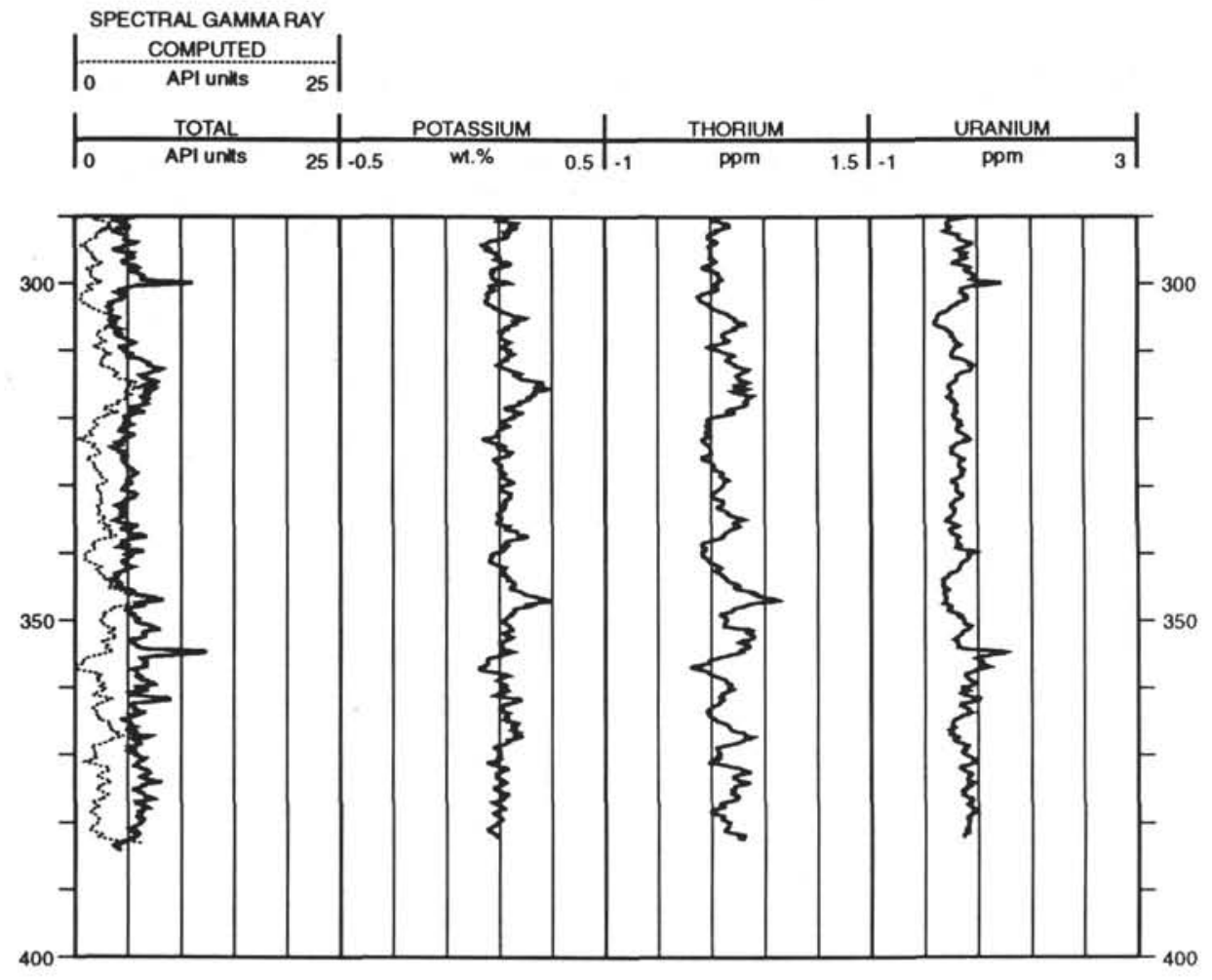

Figure 15 (continued). 


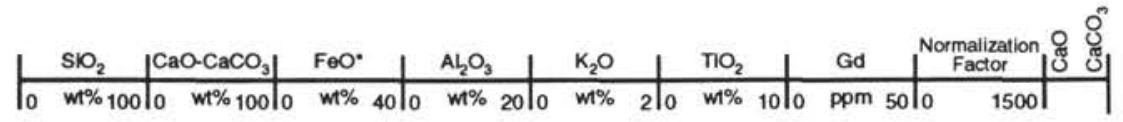

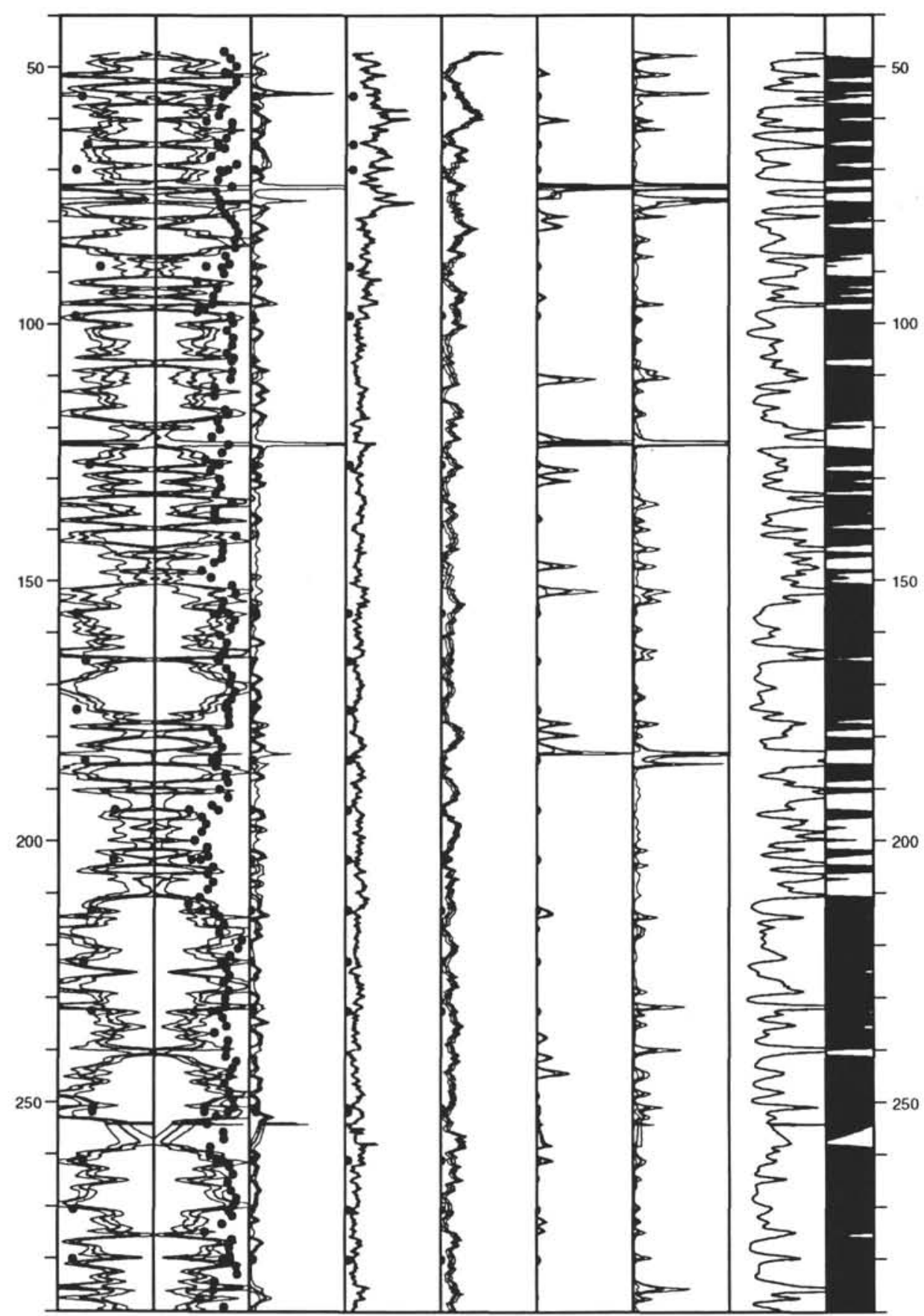

Figure 16. Estimates of calcium carbonate and major oxide-weight fractions from geochemical logs, Hole 850B. Solid diamonds and solid circles represent $\mathrm{CaCO}_{3}$ and XRF measurements, respectively (Shipboard Scientific Party, 1992g). 


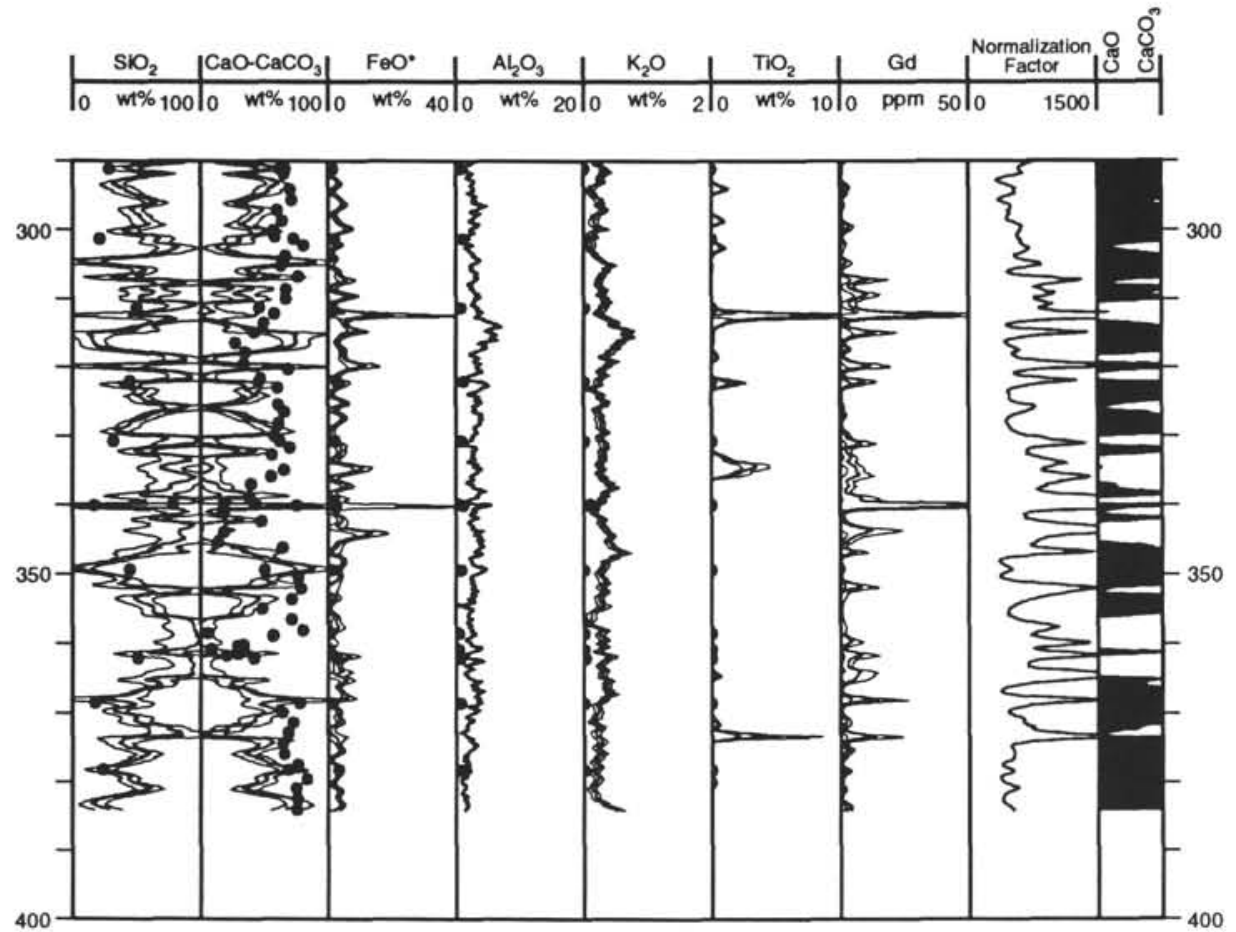

Figure 16 (continued). 

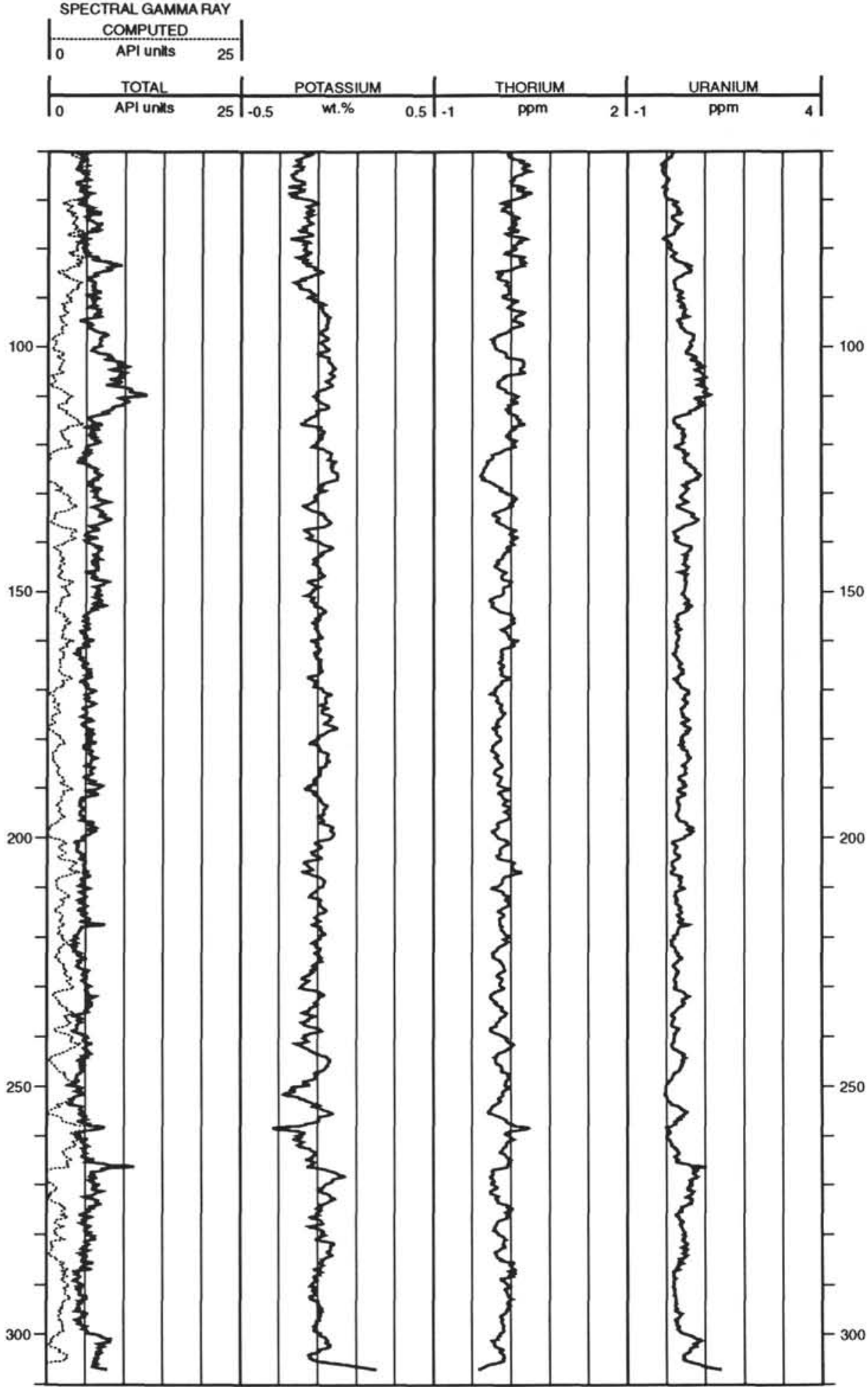

Figure 17. Processed natural gamma-ray data, Hole 851B. 


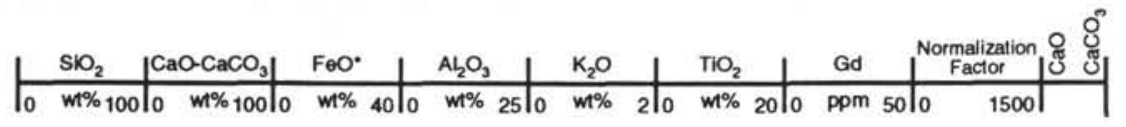

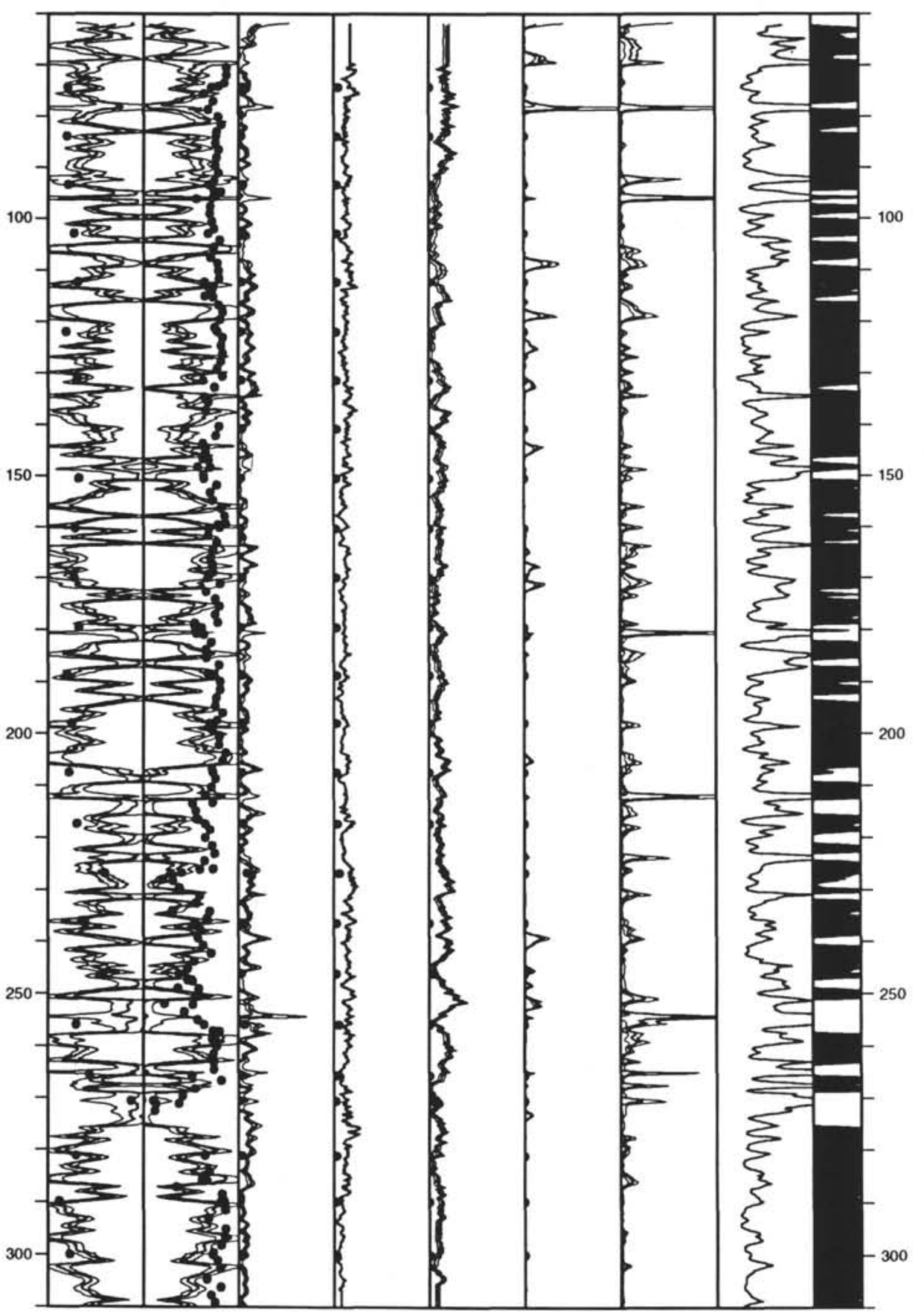

Figure 18. Estimates of calcium carbonate and major oxide-weight fractions from geochemical logs, Hole 851B. Solid diamonds and solid circles represent $\mathrm{CaCO}_{3}$ and XRF measurements, respectively (Shipboard Scientific Party, 1992h). 

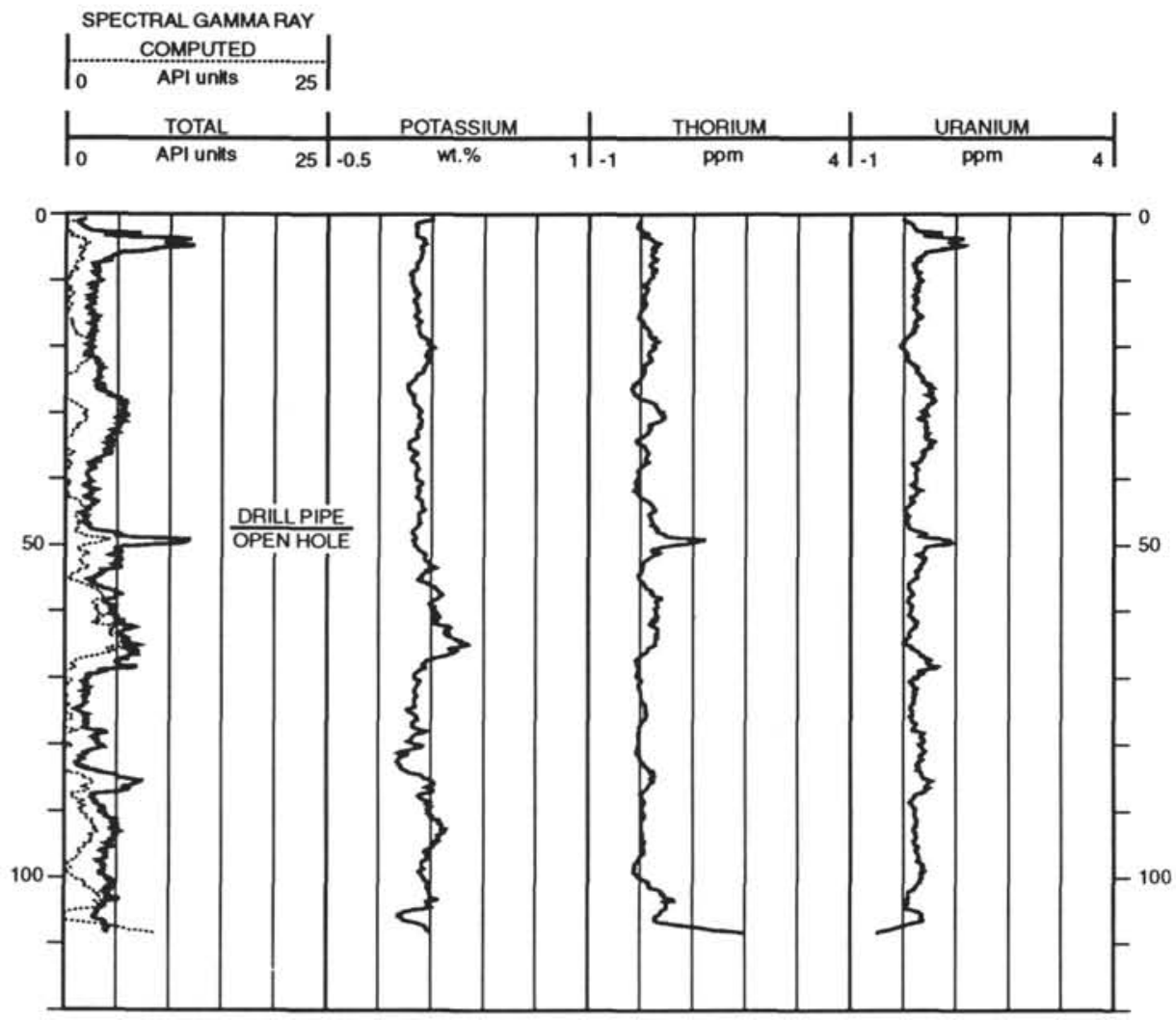

Figure 19. Processed natural gamma-ray data, Hole 852D.
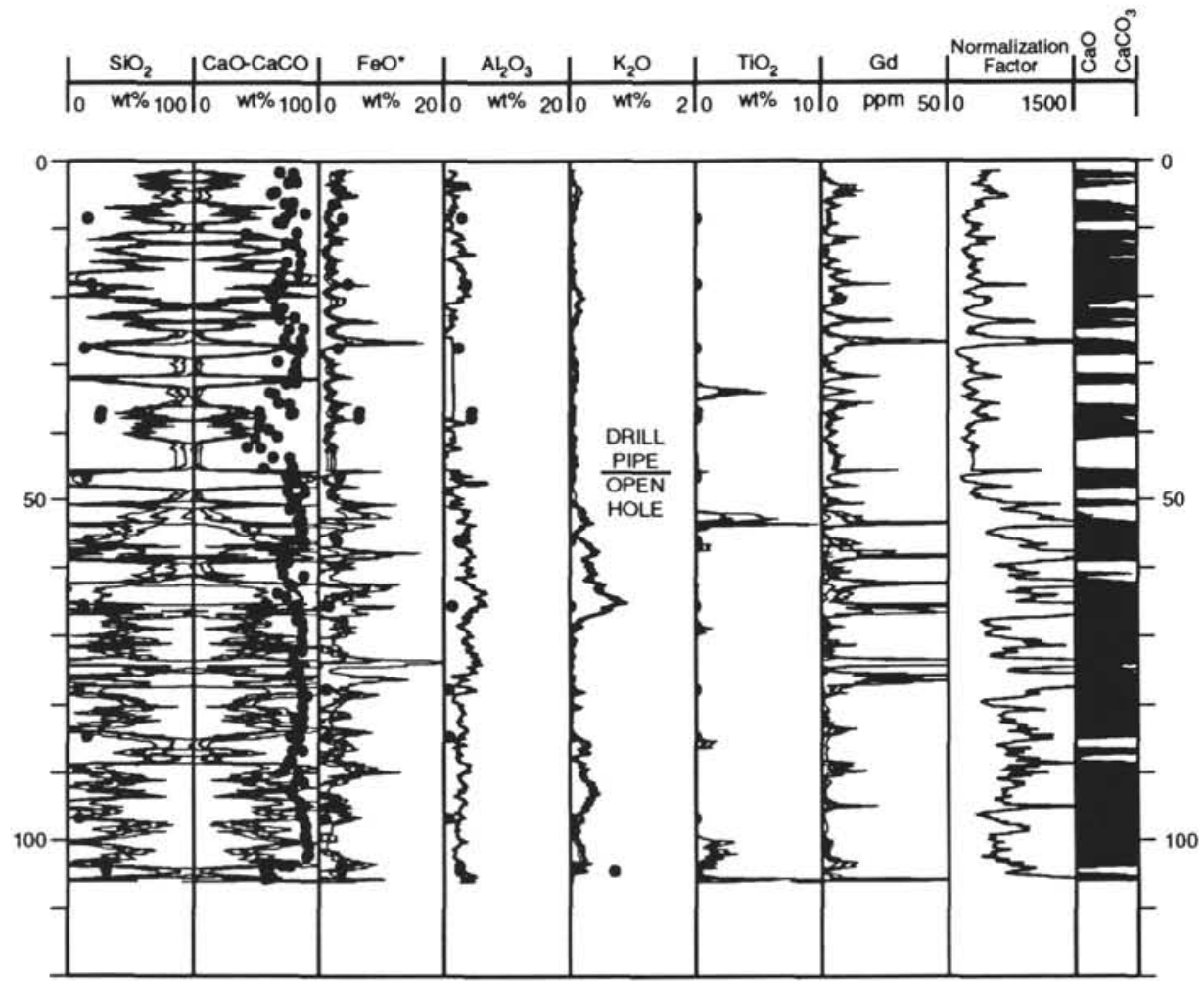

Figure 20. Estimates of calcium carbonate and major oxide-weight fractions from geochemical logs, Hole 852D. Solid diamonds and solid circles represent $\mathrm{CaCO}_{3}$ and XRF measurements, respectively (Shipboard Scientific Party, 1992i). 